\title{
Provenance analysis of the Oligocene turbidites (Andaman Flysch), South Andaman Island: A geochemical approach
}

\author{
P C BandopadhyaY* and Biswajit Ghosh \\ Department of Geology, University of Calcutta, 35 Ballygunge Circular Road, Kolkata 700 019, India. \\ ${ }^{*}$ Corresponding author.e-mail: hiyabando@yahoo.co.uk
}

The Oligocene-aged sandstone-shale turbidites of the Andaman Flysch are best exposed along the east coast of the South Andaman Island. Previously undocumented sandstone-shale geochemistry, investigated here, provides important geochemical constraints on turbidite provenance. The average $70.75 \mathrm{wt} \%$ $\mathrm{SiO}_{2}, 14.52 \mathrm{wt} \% \mathrm{Al}_{2} \mathrm{O}_{3}, 8.2 \mathrm{wt} \% \mathrm{Fe}_{2} \mathrm{O}_{3}^{\mathrm{t}}+\mathrm{MgO}$ and average $0.20 \mathrm{Al}_{2} \mathrm{O}_{3} / \mathrm{SiO}_{2}$ and $1.08 \mathrm{~K} \mathrm{O}_{2} / \mathrm{Na}_{2} \mathrm{O}$ ratios in sandstones, compare with quartzwackes. The shale samples have average $59.63 \mathrm{wt} \% \mathrm{SiO}_{2}, 20.29 \mathrm{wt} \%$ $\mathrm{Al}_{2} \mathrm{O}_{3}, 12.63$ wt $\% \mathrm{Fe}_{2} \mathrm{O}_{3}^{\mathrm{t}}+\mathrm{MgO}$ and average $2.42 \mathrm{~K} 2 \mathrm{O} / \mathrm{Na}_{2} \mathrm{O}$ and $0.34 \mathrm{Al}_{2} \mathrm{O}_{3} / \mathrm{SiO}_{2}$ ratios. Geochemical data on $\mathrm{CaO}-\mathrm{Na}_{2} \mathrm{O}-\mathrm{K}_{2} \mathrm{O}$ diagram fall close to a granite field and on $\mathrm{K}_{2} \mathrm{O} / \mathrm{Na}_{2} \mathrm{O}-\mathrm{SiO}_{2}$ diagram within an active continental margin tectonic setting. The range and average values of $\mathrm{Rb}$ and $\mathrm{Rb} / \mathrm{Sr}$ ratios are consistent with acid-intermediate igneous source rocks, while the values and ratios for $\mathrm{Cr}$ and $\mathrm{Ni}$ are with mafic rocks. Combined geochemical, petrographic and palaeocurrent data indicate a dominantly plutonic-metamorphic provenance with a lesser contribution from sedimentary and volcanic source, which is possibly the Shan-Thai continental block and volcanic arc of the north-eastern and eastern Myanmar. Chemical index of alteration (CIA) values suggests a moderate range of weathering of a moderate relief terrane under warm and humid climate.

\section{Introduction}

Clastic sedimentary rocks, sandstones and shale in particular, contain important information about the compositions, weathering conditions and tectonic settings of the provenance and associated depositional basins. Geochemistry of sandstone and shale has been widely used to obtain this information (Crook 1974; Bhatia 1983; Taylor and McLennan 1985; Bhatia and Crook 1986; Condie et al. 1992; McLennan et al. 1993). Modern sands of known tectonic settings also exhibit systematic variations in framework mineralogy and chemical composition as a function of tectonic settings and provenance types (Maynard et al. 1982; ArmstrongAltrin 2009; Garzanti et al. 2013a).
In India, geochemical investigations and provenance analysis of sediments and sedimentary/ meta-sedimentary rocks include studies from Himalaya to Great Nicobar Islands and Nicobar and Bengal Fans (Ingersoll and Suczek 1979; Garzanti and Van Haver 1988; Bhat and Ghosh 2001; Islam et al. 2002; Rashid 2002; Raza et al. 2002; Absar et al. 2009; Ghosh et al. 2012a, b; Garzanti et al. 2013a). Nevertheless, there has hardly been any attempt to study the geochemistry of turbidites (sandstone-shale rhythmites) from the Andaman-Nicobar convergent margin accretionary Island arc.

The present investigation submits major and trace element compositions for the sandstones, not determined earlier, reports chemical characteristics

Keywords. Andaman Flysch; geochemistry; provenance; Corbyn's Cove; South Andaman Island. 
of the Andaman Flysch turbidites and builds up geochemical constraints on source lithology, weathering conditions and tectonic setting of the provenance terrane and associated sedimentary basin that supplemented the petrographic data and regional studies. The Flysch succession is best exposed along the east coast of South Andaman Island near Corbyn's Cove (figure 1). In this study, Corbyn's Cove turbidite succession has been sampled and the geochemical results are used to interpret the provenance of these turbidite sandstones.

Sedimentary rocks of Paleogene and Neogene ages are ubiquitous and conspicuous in the Andaman-Nicobar Islands; ophiolites of Late Cretaceous age and meta-sedimentary rocks are of limited occurrences (figure 1). Shallow marine limestones, marls, calcareous sandstones, foraminiferal mudstones and reworked tuffs of MioPliocene age (Archipelago Group), thick and extensive, deep sea siliciclastic turbidites of Oligocene age (Andaman Flysch) and mélange unit of shallow marine, volcaniclastic turbidite sandstones and conglomerates, reefoidal limestones, olistoliths, olistostromes, and tectonic breccias (Mithakhari Group) are major sedimentary formations (table 1). The Mithakhari Group (Karunakaran et al. 1968) is redefined as Mithakhari Mélange (Acharyya 1997, 2007; Bandopadhyay 2012).

Geological mapping together with petrological and paleontological studies during sixties (Chatterjee 1964, 1967; Karunakaran et al. 1964a, b, 1968) described the geologic setting, lithology

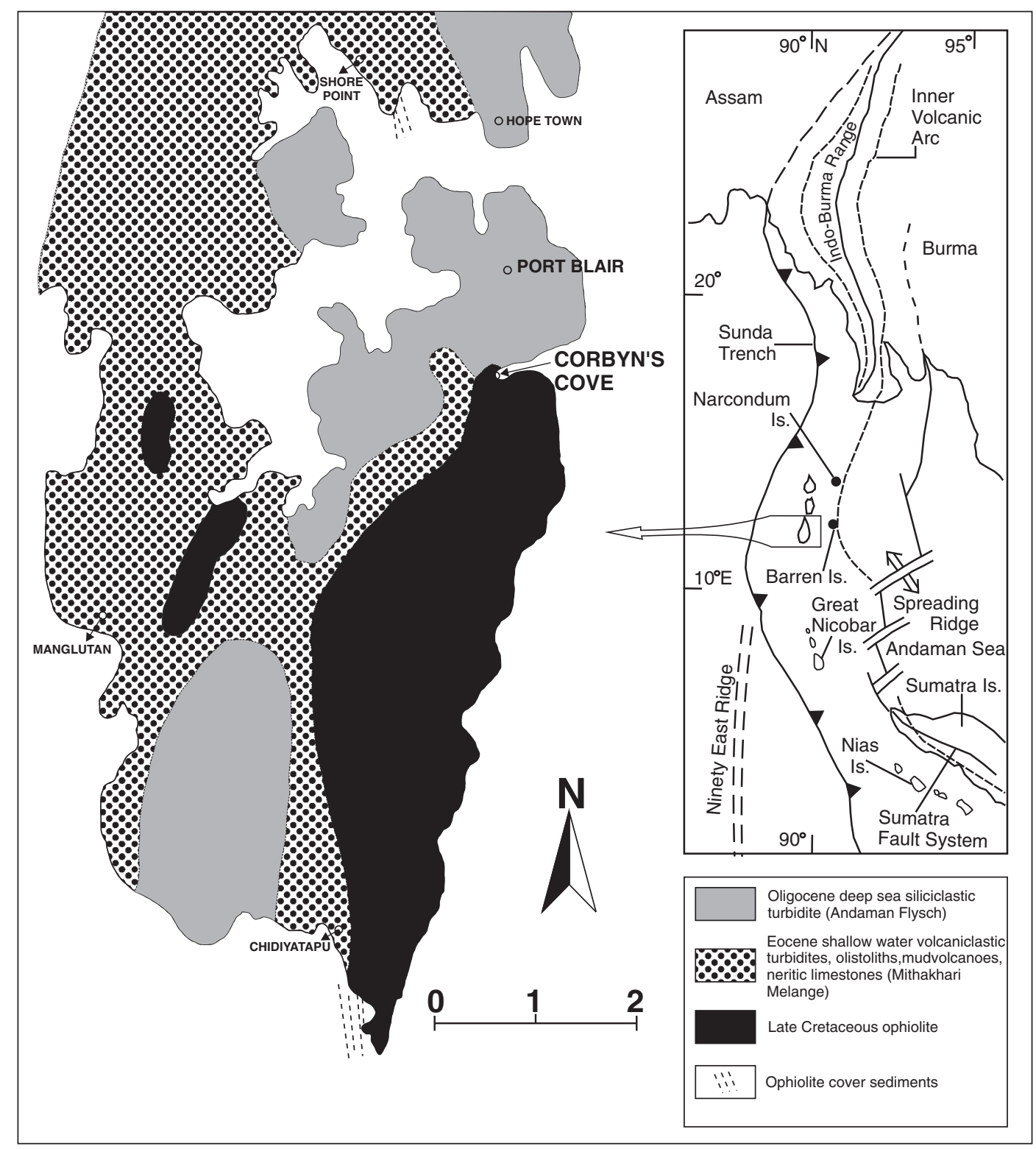

Figure 1. Outline geological map of South Andaman Island and the sample location point (Corbyn's Cove, Port Blair). Inset shows regional geotectonic setting. 


\begin{tabular}{|c|c|c|c|c|c|}
\hline Age & Group & Formation & Structure/lithology & $\begin{array}{l}\text { Sedimentary/tectonic } \\
\text { environments/settings }\end{array}$ & Fossil record \\
\hline $\begin{array}{l}\text { Holocene and } \\
\text { Pleistocene }\end{array}$ & Archipelago Group & $\begin{array}{l}\text { Neil with Neil Limestone } \\
\text { member and Chidiyatapu } \\
\text { member (Rajashekhar and } \\
\text { Reddy 2003) }\end{array}$ & $\begin{array}{l}\text { Alluvium, mangrove, coral rags, } \\
\text { swamp, cemented beach rock and } \\
\text { conglomeratic shell limestone }\end{array}$ & Subaerial to intertidal & \\
\hline Miocene-Pliocene & Archipelago Group & $\begin{array}{l}\text { Jirkatang Limestone } \\
\text { Muralat Chalk Melvile/ } \\
\text { Guiter Limestone Round } \\
\text { Chalk Strait sandstone }\end{array}$ & $\begin{array}{l}\text { Cross and parallel-laminated } \\
\text { bio-clastic limestone, marls, } \\
\text { calcareous mudstone/siltstone, } \\
\text { chalk, and felsic turbiditic tuffs }\end{array}$ & Shallow marine shelf & $\begin{array}{l}\text { Foraminifers, Lepidocyclina, } \\
\text { Miogypsina, bryozoan and algae } \\
\text { (Sharma and Srinivasan 2007) }\end{array}$ \\
\hline $\begin{array}{l}\text { Oligocene (deposition } \\
\text { between } 30 \text { and } 20 \mathrm{Ma} \text {; } \\
\text { Allen et al. 2008) }\end{array}$ & & Andaman Flysch & $\begin{array}{l}\text { Parallel-bedded quartzwacke-shale } \\
\text { turbidites, Bouma sequences } \\
\text { and sole marks are abundant. }\end{array}$ & Deep sea fan & $\begin{array}{l}\text { Barren of fossil (Chatterjee } \\
\text { 1964; Allen et al. 2008) }\end{array}$ \\
\hline \multirow[t]{2}{*}{$\begin{array}{l}\text { Late Paleocene-- } \\
\text { Eocene (deposition } \\
\text { after } 60 \mathrm{Ma} \text { and no } \\
\text { later than } 40 \mathrm{Ma} \text {; } \\
\text { Allen et al. 2008) }\end{array}$} & \multirow[t]{2}{*}{$\begin{array}{l}\text { Mithakhari Group } \\
\text { (Renamed as } \\
\text { Mithakhari Mélange } \\
\text { (Acharyya 1997; } \\
\text { Bandopadhyay } \\
\text { 2012) }\end{array}$} & $\begin{array}{l}\text { (3) Namunagarh Grit } \\
\text { including Wrightmyo } \\
\text { Nummulitic Limestone } \\
\text { member }\end{array}$ & $\begin{array}{l}\text { (3) Essentially massive and locally } \\
\text { graded and channelized beds } \\
\text { of gritty and coarse to medium } \\
\text { grained volcanolithic sandstone } \\
\text { turbidites, graded tuff, lithic- } \\
\text { poor arkoses, and algal and } \\
\text { foraminiferal limestones. } \\
\text { Trace fossils and shale flake } \\
\text { conglomerates common }\end{array}$ & $\begin{array}{l}\text { (3) Shallow water } \\
\text { basins perched on } \\
\text { to the slopes of the } \\
\text { accretionary wedge } \\
\text { and fed by several } \\
\text { small fans }\end{array}$ & $\begin{array}{l}\text { Nummulites atacicus Leymerie, } \\
\text { Assilina papillata Nuttall, } \\
\text { N. subatacicus Douville and } \\
\text { Discocyclina (middle Eocene); } \\
\text { Nummulites acutus, N. atacicus, } \\
\text { Assilina papillata, Pelatispira, } \\
\text { Biplanispira (upper Eocene) } \\
\text { (Chatterjee 1964) }\end{array}$ \\
\hline & & $\begin{array}{l}\text { (2) Hope Town-Conglomerate } \\
\text { with Tugapur Limestone } \\
\text { member }\end{array}$ & $\begin{array}{l}\text { (2) Matrix to clast-supported } \\
\text { polymictic conglomerates and } \\
\text { sandstone with shale and } \\
\text { foraminiferal limestones }\end{array}$ & $\begin{array}{l}\text { (2) Same as } \\
\text { Namunagarh Grit }\end{array}$ & $\begin{array}{l}\text { Distichoplax biserialis in } \\
\text { limestones (late Paleocene) } \\
\text { (Chatterjee 1964). Assilina } \\
\text { daveisi de Cizancourt in } \\
\text { conglomerate matrix (lower } \\
\text { Eocene) (Chatterjee 1964) }\end{array}$ \\
\hline $\begin{array}{l}\text { Late Cretaceous } \\
\text { to Paleocene } \\
(95 \pm 1.3 \mathrm{Ma} \text { age } \\
\text { of plagiogranite, } \\
\text { Pedersen } \text { et al. } 2010)\end{array}$ & $\begin{array}{l}\text { Ophiolite including } \\
\text { radiolarian chert and } \\
\text { pelagic calcareous } \\
\text { mudstone }\end{array}$ & (1) Lipa black shale & $\begin{array}{l}\text { (1) Pyritiferous black shale with } \\
\text { olistoliths in sheared argillite } \\
\text { matrix. Chert, muddy carbonate, } \\
\text { mudstone, basalt, gabbro, } \\
\text { plagiorgranite, diorite, } \\
\text { serpentinised harzburgite, } \\
\text { dunite, pyroxenite }\end{array}$ & $\begin{array}{l}\text { (1) Euxinic environment/ } \\
\text { trench setting. Uplifted } \\
\text { segments of ocean floor } \\
\text { and oceanic crust } \\
\text { forming accretionary } \\
\text { ridge }\end{array}$ & $\begin{array}{l}\text { Spumellarion radiolarian, } \\
\text { Globigerina eugubina, } \\
\text { G. trilloculinsides, Globorotalia } \\
\text { compressa and Globotruncana } \\
\text { (Roy et al. } 1988 \text { ) }\end{array}$ \\
\hline Pre-Ophiolite & Older metasediments & & $\begin{array}{l}\text { Quartz-sericite-muscovite } \\
\text { schist, crystalline limestones, } \\
\text { quartzite }\end{array}$ & $\begin{array}{l}\text { Represent elements } \\
\text { of passive continental } \\
\text { margin }\end{array}$ & \\
\hline
\end{tabular}


and faunal content of the rocks of AndamanNicobar Islands and established the stratigraphy. Several subsequent studies have made significant contribution to the knowledge of geology, sedimentology, structure, stratigraphy, petrology, geochemistry, ophiolites and geodynamics (Roy 1983; Haldar 1985; Vohra et al. 1989; Pandey et al. 1992; Jafri et al. 1993; Acharyya 1997, 2007; Bandopadhyay and Ghosh 1998; Chakraborty et al. 1999; Pal et al. 2003; Bandopadhyay 2005, 2012; Allen et al. 2008; Bandopadhyay et al. 2008, 2009; Chakraborty and Khan 2009; Pal and Bhattacharya 2010; Pedersen et al. 2010; Sarma et al. 2010; Pal 2011; Garzanti et al. 2013a; Jafri and Sheikh 2013 and many others). Srinivasan and his coworkers (Sharma and Srinivasan 2007 and the references therein) have done a detailed study of the Neogene sequences of the Andaman-Nicobar Islands. In recent times, Ghosh et al. (2009, 2012a, b) studied the occurrences and petrology of ophioliteassociated podiform and layered chromites of Andaman Islands and discussed the petrogenetic implications of the chromite occurrences. Allen et al. (2008) carried out fission track (FT) and $\mathrm{U}-\mathrm{Pb}$ dating of terrigeneous and volcanogenic zircon and apatite from key Paleogene sedimentary formations and provided robust and new constraints on the ages of these formations and on sedimentation-uplift history of the accretionary ridge, studying the rocks from South Andaman Island only. The Andaman-Nicobar accretionary ridge during the Oligocene collisional events between India and Asia (Acharyya 2007; Curray and Allen 2008) witnessed extensive development of deep marine siliciclastic turbidites (Andaman Flysch) for which provenance has for long, been poorly known. On the basis of palaeocurrent directions, a distal continental source beyond the northern and northeastern frontiers of Burma was broadly suggested (Karunakaran et al. 1964a, b, 1968; Chakraborty and Pal 2001).

\section{Regional tectonic setting}

The late Cretaceous-Paleogene convergence and collisional events involving subduction, off-scraping, accretion and uplift of ocean floor sediments and ophiolites along the eastern margin of the IndoAustralian plate created a north-south trending long accretionary ridge of highlands and islands that contains the Andaman-Nicobar Islands which is a non-volcanic outer arc accretionary ridge. To the north, the outer arc ridge joins the ArakanYoma range representing the southern prolongation of the Indo-Burma accretionary ranges (IBR) of collisional orogen. To the south, the ridge joins the outer arc islands (Nias, Banyak, Mentawai islands) of the Sumatran arc-trench system. This curvilinear belt of highlands and islands has been described as Western Sunda Arc (Curray and Allen 2008). Modern tectonic setting of the Andaman Sea region shows Andaman Sea to the east of Andaman Islands. This sea is a back arc basin above the subduction zone and regarding the origin and evolution of this basin a two-stage tectonic model has been suggested (Khan and Chakraborty 2005). A three-phase tectonic evolution since Late Oligocene for the basin has also been proposed based on the multibeam swath bathymetry, magnetic and seismological studies (Raju 2005). The volcanic islands on the Andaman Sea, Barren (active) and Narcondam (dormant) are part of the quaternary and recent inner arc volcanic belt extending from central Myanmar to Sumatra. The volcano at Barren Island since 1991 shows intermittent Strombolian eruptions (Bandopadhyay et al. 2014). The Andaman-Java trench lies to the west of the Andaman-Nicobar Islands (figure 1). The IBR and the Arakan-Yoma ridge in its inner or eastern part are composed primarily of Upper Cretaceous to Paleogene deep-water sediments and mélange containing blocks of gabbros, pillow basalt, serpentinite, chert, limestone and schist (Mitchell 1993). The sedimentary formations continue southward to the Andaman-Nicobar Islands where they overlie ophiolite complexes (Acharyya 1997). Farther east, the IBR is flanked by the central Myanmar (Burma) basin representing the site of continental margin between the subduction zone to the west and the arc to the east. The central Burma basin is drained by the Irrawaddy River and to the east of the basin there lies the Mogok metamorphic belt and Shan-Thai continental block of eastern Myanmar. The metamorphic belt extends for over 1500 $\mathrm{km}$ along the western margin of Shan plateau constituted of Precambrian to Paleozoic continental metamorphic and sedimentary rocks and intrusive igneous assemblages.

In this belt of active subduction with a strong, strike slip component, resulted from oblique convergence, off-scraped sediments and oceanic crust (ophiolite) from the subduction decollement zone has led to the formation of a subaqueous accretionary prism consisting of easterly dipping imbricate stack of thrust slices (Roy 1983; Curray 2005). Continuous underplating of the descending slab below the overriding plate beyond the margin of the trench causes up-building of the prism which with subsequent uplifts have given rise to the formation of Andaman-Nicobar subaerial ridge (islands). The ridge extends for about $\sim 700 \mathrm{~km}$ with a maximum width of $\sim 31 \mathrm{~km}$. Olistoliths, olistostromes, slumps, slides, accretionary deformation structures, ophiolite and sedimentary mélanges, tectonic breccia, active mud diapirism, and high 
seismicity, all that are characteristic of convergent margin accretionary settings, have been docu mented from Andaman Islands (Bandopadhyay 2012).

\section{Andaman Flysch}

Bounded between the Mithakhari Group below and the Archipelago Group above, the Andaman Flysch ( 23000 m thick, Pal et al. 2003) is exposed as detached outcrops mainly along the west coast of north Andaman to south Andaman Islands. It is also exposed on the east coast of South Andaman Island from Mt. Harriet to Corbyn's Cove, where road cutting sections and wave-cut shore platforms at low tide exhibit excellent exposures of turbidites (figure 2a). The Corbyn's Cove exposures are most completely documented sequences of Andaman Flysch turbidites (Chakraborty and Pal 2001). The Flysch turbidites cover almost the entire area of Great Nicobar Island. Bandopadhyay and Ghosh (1998) and Bandopadhyay (2012) described the geologic setting and key sedimentary, petrographic and palaeontologic features of the late Paleocene-Eocene and Oligocene turbidites of the
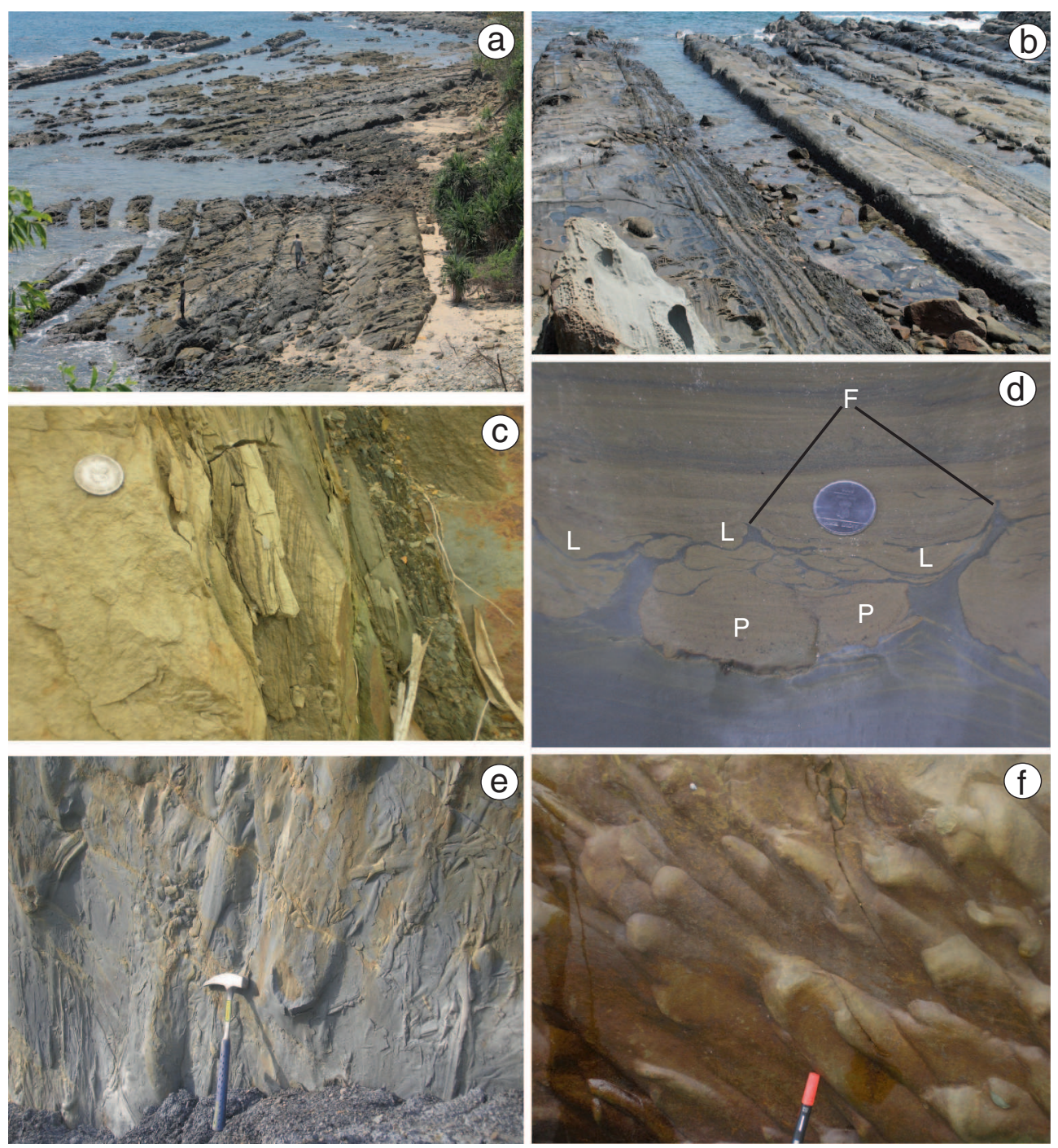

Figure 2. Field photographs of the Andaman Flysch turbidites. (a) Wave cut shore platform during low tide exposes faulted sequences of the meter-scale thick, steep to vertical dipping beds of turbidite sandstones interbedded with much thinner basinal shales on the east coast of South Andaman Island near Corbyn's Cove. Note the sharp change in strike of the beds due to faulting and the fault-gauge is filled with sea water, a man, 5.6 feet tall stands on a thick sandstone bed; (b) Meter-thick beds of sandstone showing massive lower and laminated upper part (Bouma Ta and Tb intervals) overlain by thinly laminated fissile shale; (c) Current ripple laminations on the top of a thick sandstone bed; (d) Thick sandstone bed loaded (L) into the underlying shale bed. Detached pillows $(\mathrm{P})$ of sandstones within shale that intruded into the overlying sandstone bed and produce flame (F) structures; (e) A variety of sole marks at the base of an overturned sandstone bed, location behind airport; (f) A swarm of flute casts (flow direction from left to right) exposed due to overturning of the turbidite sandstone bed, South Point coastal section, Port Blair. 
Andaman-Nicobar Islands and re-interpreted the age and depositional setting of the Paleogene turbidites studied earlier (Chakraborty and Pal 2001). The studied turbidites consist of meter-thick beds of light greenish grey to yellowish grey, indurated sandstones alternating with $\mathrm{cm}$ to $\mathrm{dm}$ thick beds of highly fissile and thickly-laminated dark grey shale. Individual sandstone beds are parallel-sided, up to 2-m thick and are laterally persistent, uniform in thickness, texture and composition, and show Bouma cycles. The sandstone beds with Bouma cycles, seen as most complete, start with a massive or normally graded interval at the base and grade upward to parallel laminated interval. These correspond to Bouma Ta and Tb divisions (figure 2b). A small scale current ripple-laminated interval often overlies the parallel laminated or massive interval and represents Tc division (figure 2c). However, the topmost two Bouma divisions ( $\mathrm{Td}$ and $\mathrm{Te}$ ) are difficult to separate in the field, and the thick and laminated beds of dark grey shale are considered as Td division. There is very little pelite division $(\mathrm{Te})$ preserved. Chakraborty and Pal (2001) described topand bottom-truncated Bouma cycles consisting of
Ta-c, Tb-c, Tb-e and Td-e divisions. Individual sandstone beds are marked by a sharp base with an assemblage of sole marks (flute and groove casts and flame structures) (figure $2 \mathrm{~d}-\mathrm{f}$ ) and a gradational top with the overlying shale. Karunakaran et al. (1968) and Chakraborty and Pal (2001) recorded southward palaeocurrent direction based on orientation of sole marks. They suggested sediment transport from the north and northeastern frontiers of Burma. Allen et al. (2008) observed that the fine to very fine grained Flysch sandstones compare closely with modern sands of homologous grain size from the Irrawaddy delta in Myanmar.

\section{Sandstone petrography \\ 4.1 Framework minerals}

The matrix-rich, immature turbidite sandstones (figure 3a) have, for long, been described as greywackes (Karunakaran et al. 1964a, b and subsequent studies). Recognizing the quartzose nature of
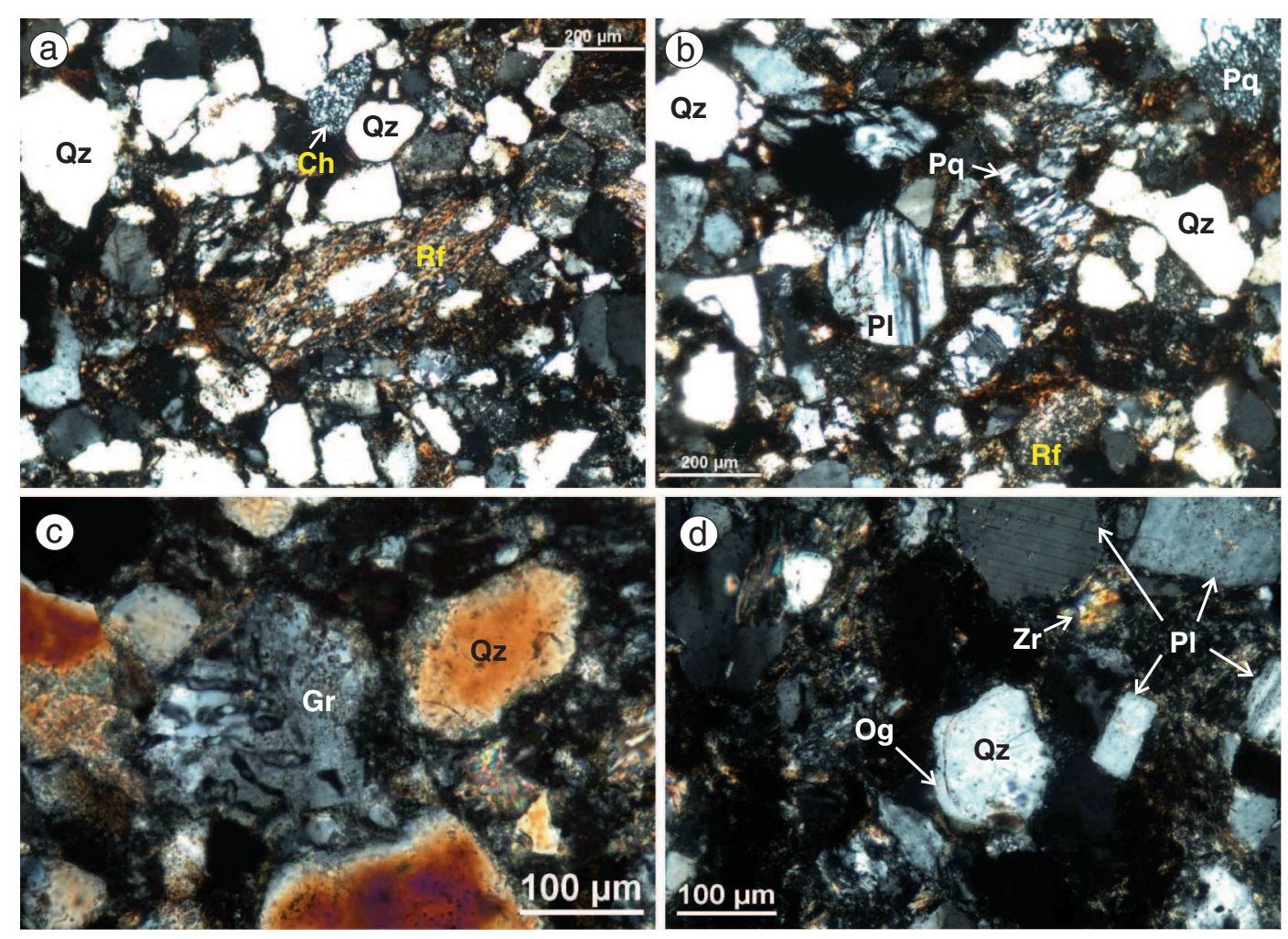

Figure 3. Photomicrographs of turbidite sandstones, Corbyn's Cove. (a and b) General view of immature quartzwacke sandstones; note schistose rock fragment (Rf), rounded chert grain ( $\mathrm{Ch}$ ) and abundance of monocrystalline quartz (Qz); (b) shows an almost fresh euhedral plagioclase, angular polycrystalline quartz ( $\mathrm{Pq}$ ) (middle of the photo and arrowed) consisting of numerous flattened (stretched) subgrains and strongly sutured subgrain contacts; (c) sand grain showing intergrowth of quartz in k-feldspar (graphic texture) and quartz grain (reddish colour) showing diffuse and corroded grain boundary; (d) shows abraded overgrowth of quartz $(\mathrm{Og})$ on a detrital quartz grain and almost fresh untwined and twined feldspars; note a zircon grain in the middle (arrowed). 
the sandstones, Bandopadhyay and Ghosh (1998) described the sandstones as quartzwackes and observed almost uniform framework compositions in different samples of the sandstones studied from Corbyn's Cove. Quartz represents the main framework components; feldspar and lithic fragments occur next in abundance. Point count analyses (Allen et al. 2008) indicate that the sandstones have moderate quartz (Q) content (Q: $49 \pm 2 \%$ ) and contain subequal amount of lithic (L) grains (L: $29 \pm 6 \%$ ) and feldspar (F) (F: $22 \pm 6 \%$; plagioclase feldspar $39 \pm 9 \%$ ). Garzanti et al. (2013a) provided a more actualistic nomenclature stating that the sandstones are litho-feldspatho quartzose to feldspatho-litho quartzose, metamorphiclastic with metapelites/metapsamite, rare felsic volcanics and a few sedimentary rock fragments and micas. Such petrofacies-oriented terminology provides more definite information on provenance compared to terms such as greywackes and arkoses (Ingersoll 1983). According to the classification of metamorphic rock fragments (Garzanti and Vezzoli 2003), the metamorphiclastic grains are mainly fragments of low- to medium-grade and rarely high grade metamorphic rocks (quartz-mica schist, argillites and metaquartzite) (figure $3 \mathrm{a}, \mathrm{b}$ ). Altered basalts and felsic volcanic grains occur in minor quantity. Sedimentaclasts include rounded grains of chert and siltstone clasts. The whole or broken, rounded sand grains, quartz with abraded overgrowth, well-rounded zircon grains, grain showing graphic texture (intergrowth of quartz in k-feldspar) and euhedral plagioclase may not be ubiquitous but are invariably conspicuous and important framework components (figure 3c and d). Among micaceous framework minerals, white muscovites followed by green-brown biotites are common. Chlorite and sericite are present in lesser amount. Micas occur as large and small flakes to very finely comminuted shreds. In places, flakes are oriented parallel to the bedding and hence to each other. Quartz grains show unit and undulose extinction but they are mostly undulose and monocrystalline variety. The common polycrystalline grains consist of a few large subgrains of unequal sizes, showing interlocking grain contacts or of several, small and flattened (stretched) subgrains showing sutured grain contacts. Feldspars comprise untwinned and chess-board twinned, kfeldspars or thin, lamellar-twinned Na-plagioclase. They are both fresh and altered; the latter looks turbid and cloudy. Zircon, tourmaline, rutile and chrome-spinel, together make up the bulk of the heavy mineral assemblages. The light pink coloured zircons comprise rounded and prismatic grains, similar to recycled and volcanic zircon respectively. Detrital framework compositions plot within recycled orogenic province of the standard QFL diagram of Dickinson et al. (1983) (figure 15 of Allen et al. 2008).

\subsection{Texture and diagenesis}

The immature turbidite sandstones show many textures and mineralogical changes resulted from moderate compaction and burial diagenetic alteration. The grain size of the studied turbidite sandstones ranges from coarse silt to medium sand but most samples are fine sand sizes. Framework quartz and feldspar grains show poor to moderate sorting but commonly very poor rounding (figure 3a, b). They are commonly angular to subangular; subrounded and rounded grains are relatively uncommon. The low sphericity framework grains are generally, moderately but locally tightly packed, showing point or long tangential grain contacts and at places, concavo-convex contacts. Diagenetically altered grains show corroded as well as diffuse grain boundaries fading gradually into the surrounding matrix (Bandopadhyay and Ghosh 1998). Diagenetically altered feldspars and muscovites show formation of illitic and kaolinitic clays and the altered biotites show formation of chlorite, along and across the cleavages and fractures. Diagenetic alteration of volcanic fragments produces chlorite, which forms along with epidote within volcanic rock fragments. Clay minerals occurring as mechanical infiltration, where observed, show thin coating around unaltered detrital grains. Alteration of framework grain produces epimatrix, while infiltration of clay minerals represents early formed protomatrix (Dickinson 1970). Micas and labile rock fragments were deformed and quashed between quartz and feldspar, and were transformed into pseudomatrix (Dickinson 1970). The framework interstices are commonly filled with dirty brown ferruginous and carbonaceous matter and fibrous clay minerals. Illite is the most common matrix mineral followed by chlorite and kaolinite. Chlorite commonly forms a pale-green fibrous aggregate. The matrix, much of which is of diagenetic origin, varies between 13 and 39 volume $\%$ of the rock and often exceeds 20\%. Post-depositional alteration of minerals, particularly of mafic silicates often makes it difficult to evaluate the original clastic composition of the turbidite sandstones and in turn determination of provenance/s, source lithologies, and tectonic settings. The digenetic changes although destroy the framework mineralogy, do not affect the bulk chemical composition despite local diffusion of $\mathrm{Na}, \mathrm{K}, \mathrm{Mg}$ and $\mathrm{Ca}$. The problem of diffusion of elements can be minimized in case of rapid burial. The textural and mineralogical immaturity of the sandstones and the occurrence of fresh Na-feldspars are consistent with rapid burial and concomitant reduction of effective permeability. 


\section{Geochemistry}

\subsection{Sampling and analytical methods}

Loss of elements occur during weathering at the source region reflected in CIA values and also within sedimentation realm. Grain-size sorting during transport of sediments and mineralogical reconstitution during diagenesis, resulted in changes of chemical composition. Weathering and durability of detrital minerals in equatorial climate as in the present case, have also been investigated by Garzanti et al. (2013b). To minimize the effect of grain size sorting during transport and the fact that fine-grained sediments typically represent more homogeneously mixed sources (McLennan et al. 1993), samples of both fine-grained sandstones and the associated shale have been analyzed (cf. Roser and Korsch 1986). Diagenetic removal of elements also appears minimal because of rapid burial of the Flysch sediments (Bandopadhyay and Ghosh 1998; Allen et al. 2008). Eight representative samples of visibly fresh sandstone and three of interbedded shale were analyzed for major and a number of trace elements. This study based on a limited number of chemical analyses, is an initial synthesis intended to focus further study. Nevertheless, the geochemical data appear useful for an improved understanding of the petrogenesis of turbidites. Major element analyses were recalculated to $100 \mathrm{wt} \%$ on a volatile-free basis in order to achieve a more meaningful comparison. Major element concentrations given in wt\% were determined by X-ray fluorescence spectrometric (Philips PW 1400) and the trace elements given in ppm were determined by Atomic Absorption Spectrometric (AAS) techniques. A selection of USGS standards (G2, G3, GSR-1 and BCR-1) and inhouse standards were used for calibration. The analyses were performed at the chemical laboratory of the Geological Survey of India, Eastern Region. FeO and LOI were determined by wet chemistry.

\subsection{Major elements}

The range and average of concentrations of major elements and ratios of key elements for sandstone and shale of the Andaman Flysch are presented in table 2. To obtain a more realistic view, the average chemical compositions of the sandstone and shale are compared with average composition of comparable rocks of different provenances and tectonic settings (table 3 ). The consistent analytical results are reflected by the narrow range of variations in concentrations of major elements for both sandstone and shale. The $\mathrm{K}_{2} \mathrm{O}$ and $\mathrm{Na}_{2} \mathrm{O}$ contents and their ratios show a narrow range of variations and the total alkali $(\mathrm{Na}+\mathrm{K})$ content in the samples varies also within a narrow range (table 2). This could be attributed to redistribution of alkali elements during post-depositional alteration, which has not significantly affected the bulk composition. The Flysch sandstone-shale couplets show an increase of $\mathrm{K}_{2} \mathrm{O} / \mathrm{Na}_{2} \mathrm{O}$ ratio from sandstones to shale and $\mathrm{SiO}_{2}$ content from shale to sandstone, consistent with analysis of sandstone--mudstone suites of the greywackes, New Zealand (Roser and Korsch 1986). The CaO content in the seven samples ranges between 0.33 and $0.67 \mathrm{wt} \%$ (average $0.41 \mathrm{wt} \%$ ) comparing with that of quartzwackes (Condie et al. 1992). The very low $\mathrm{CaO}$ contents reflect that the calcium resides in silicate phases and is thus considered for calculating Chemical Index of Alteration (CIA) (Nesbitt and Young 1982). One sample (no. CFHS1) with 5.99 wt\% $\mathrm{CaO}$ shows presence of carbonate cement in petrographic thin section. All sandstone samples record extremely low $\mathrm{MnO}$ content (table 2), similar to that recorded by Banerjee and Banerjee (2010). The negative correlations of $\mathrm{SiO}_{2}$ with most of the major elements in both sandstones and shale are due to most of the silica being sequestered in quartz (cf. Rahman and Suzuki 2007).

The range and average concentration of major elements of the interbedded shale (table 2) are compared with North American Shale Composite (NASC) (Gromet et al. 1984) and Post-Archean Average Shale (PAAS) (table 3). The NASC represents large volumes of very fine grained sediment that are thought to reflect the 'average composition' of upper continental crust; it is almost identical to the Post-Archean Average Shale (PAAS) of Taylor and McLennan (1985). The geochemistry of interbedded shales favourly compares to that of average composition of PAAS and NACS except lower $\mathrm{CaO}$ content compared to NACS and PAAS. When compared with mudrocks of continental arc, back arc and forearc basins (McLennan et al. 1990), the average composition of Flysch shale lies close to that of continental arc basin.

The chemical index of alteration (CIA; Nesbitt and Young 1982) is used to check the mobility of major elements that might have occurred, especially during diagenesis. In order to evaluate the effects of weathering, ternary diagrams that plot the molar proportions of $\mathrm{Al}_{2} \mathrm{O}_{3}$, the sum of $\mathrm{CaO}$ (in silicate fraction only) and $\mathrm{Na}_{2} \mathrm{O}$, and $\mathrm{K}_{2} \mathrm{O}(\mathrm{A}-\mathrm{CN}-$ $\mathrm{K})$ were constructed (Nesbitt and Young 1982). The CIA values for sandstones and shale (table 2) range between 72.70 and 85.25 (average 77.10) and for interbedded shale between 78.12 and 78.69 (average 78.46). The CIA values marginally exceed those of Phanerozoic shales (CIA $=70-75$; Nesbitt and Young 1982). The current analyses of Flysch 


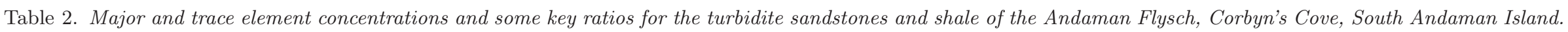

\begin{tabular}{|c|c|c|c|c|c|c|c|c|c|c|c|c|c|}
\hline \multirow{3}{*}{$\begin{array}{l}\text { Sl. no. } \\
\text { Sample no. }\end{array}$} & \multicolumn{8}{|c|}{ Sandstone } & \multicolumn{4}{|c|}{ Shale } & \multirow[b]{3}{*}{ Avg } \\
\hline & 1 & 2 & 3 & 4 & 5 & 6 & 7 & 8 & & 9 & 10 & 11 & \\
\hline & CFS1 & CFS2FG & CFS2YG & CFS3-11 & CFS4-12 & CFHS1 & CF205 & CF305 & Avg & CFM1 & CFM2 & CFM3 & \\
\hline \multicolumn{14}{|c|}{ Major element contents and their correlative ratios } \\
\hline $\mathrm{SiO}_{2}$ & 70.09 & 71 & 70.24 & 73.91 & 70.71 & 68.53 & 71.94 & 69.64 & 70.75 & 59.15 & 59.71 & 60.02 & 59.63 \\
\hline $\mathrm{TiO}_{2}$ & 1.05 & 1.01 & 1.2 & 0.94 & 0.91 & 0.83 & 1.08 & 1.13 & 1.01 & 1.26 & 1.25 & 1.17 & 1.23 \\
\hline $\mathrm{Al}_{2} \mathrm{O}_{3}$ & 14.55 & 13.98 & 13.53 & 13.18 & 15.26 & 12.73 & 15.65 & 17.35 & 14.52 & 20.18 & 20.79 & 19.9 & 20.29 \\
\hline $\mathrm{Fe}_{2} \mathrm{O}_{3}$ & 3.79 & 3.23 & 3.75 & 3.26 & 3.47 & 2.49 & 5.13 & 7.68 & 4.1 & 5.59 & 3.41 & 5.26 & 4.75 \\
\hline $\mathrm{FeO}$ & 2.35 & 2.6 & 2.62 & 2.05 & 1.99 & 2.33 & 0.83 & 0.09 & 1.95 & 3.86 & 5.46 & 4.13 & 4.48 \\
\hline $\mathrm{MgO}$ & 2.93 & 3 & 3.4 & 2.3 & 2.47 & 2.42 & 1.83 & 1.19 & 2.44 & 4.22 & 3.28 & 3.76 & 3.75 \\
\hline $\mathrm{MnO}$ & 0.06 & 0.06 & 0.06 & 0.04 & 0.05 & 0.33 & 0.04 & 0.02 & 0.08 & 0.1 & 0.07 & 0.15 & 0.11 \\
\hline $\mathrm{CaO}$ & 0.67 & 0.64 & 0.63 & 0.33 & 0.49 & 5.99 & 0.06 & 0.06 & 1.12 & 0.46 & 0.43 & 0.44 & 0.44 \\
\hline $\mathrm{Na}_{2} \mathrm{O}$ & 2.31 & 2.21 & 2.37 & 1.89 & 2.36 & 1.79 & 1.27 & 0.44 & 1.83 & 1.46 & 1.34 & 1.46 & 1.42 \\
\hline $\mathrm{K}_{2} \mathrm{O}$ & 2.05 & 2.05 & 2.08 & 1.97 & 2.14 & 2.41 & 2.01 & 2.22 & 2.11 & 3.55 & 4.05 & 3.52 & 3.71 \\
\hline $\mathrm{P}_{2} \mathrm{O}_{5}$ & 0.16 & 0.14 & 0.13 & 0.14 & 0.14 & 0.14 & 0.12 & 0.13 & 0.13 & 0.12 & 0.15 & 0.11 & 0.13 \\
\hline Total & 100.01 & 99.92 & 100.01 & 100.01 & 99.99 & 99.99 & 99.96 & 99.95 & & 99.95 & 99.91 & 99.92 & \\
\hline LOI & 3.55 & 3.42 & 3.82 & 3.39 & 3.85 & 7.22 & 1.31 & 5.01 & & 8.7 & 8.38 & 7.93 & \\
\hline $\mathrm{Fe}_{2} \mathrm{O}_{3}(\mathrm{t})$ & 6.13 & 5.92 & 6.4 & 5.34 & 5.39 & 4.71 & 5.91 & 7.33 & 5.89 & 8.99 & 8.59 & 9.01 & 8.86 \\
\hline CIA & 74.31 & 74.04 & 72.7 & 75.87 & 75.35 & N.D. & 82.41 & 85.25 & 77.1 & 78.67 & 78.12 & 78.59 & 78.46 \\
\hline $\mathrm{Al}_{2} \mathrm{O}_{3} / \mathrm{SiO}_{2}$ & 0.21 & 0.2 & 0.19 & 0.18 & 0.22 & 0.19 & 0.21 & 0.24 & 0.2 & 0.34 & 0.35 & 0.33 & 0.34 \\
\hline $\mathrm{SiO}_{2} / \mathrm{Al}_{2} \mathrm{O}_{3}$ & 4.81 & 5.07 & 5.19 & 5.6 & 4.63 & 5.38 & 4.59 & 4.01 & 4.91 & 2.93 & 2.87 & 3.02 & 2.94 \\
\hline $\mathrm{K}_{2} \mathrm{O} / \mathrm{Na}_{2} \mathrm{O}$ & 0.89 & 0.93 & 0.88 & 1.04 & 0.91 & 1.35 & 1.58 & 5.04 & 1.08 & 2.43 & 2.43 & 2.41 & 2.42 \\
\hline $\begin{array}{l}\mathrm{Al}_{2} \mathrm{O}_{3} / \\
\mathrm{CaO}+\mathrm{Na}_{2} \mathrm{O}\end{array}$ & 4.88 & 4.9 & 4.51 & 5.94 & 5.35 & 1.64 & 11.74 & 34.02 & 9.12 & 10.51 & 11.18 & 10.47 & 10.72 \\
\hline $\mathrm{K}_{2} \mathrm{O}+\mathrm{Na}_{2} \mathrm{O}$ & 4.36 & 4.26 & 4.45 & 3.86 & 4.5 & 4.2 & 3.28 & 2.66 & 3.94 & 5.01 & 5.01 & 4.9 & 4.97 \\
\hline $\begin{array}{l}\mathrm{Fe}_{2} \mathrm{O}_{3}(\mathrm{t})+ \\
\mathrm{MgO}\end{array}$ & 9.07 & 8.92 & 8.74 & 7.64 & 7.84 & 7.13 & 7.74 & 8.52 & 8.2 & 13.21 & 11.87 & 12.77 & 12.63 \\
\hline $\mathrm{Al}_{2} \mathrm{O}_{3} / \mathrm{TiO}_{2}$ & 13.85 & 13.84 & 11.27 & 14.02 & 16.79 & 15.33 & 14.49 & 15.35 & 14.36 & 16.02 & 16.63 & 17 & 16.55 \\
\hline
\end{tabular}




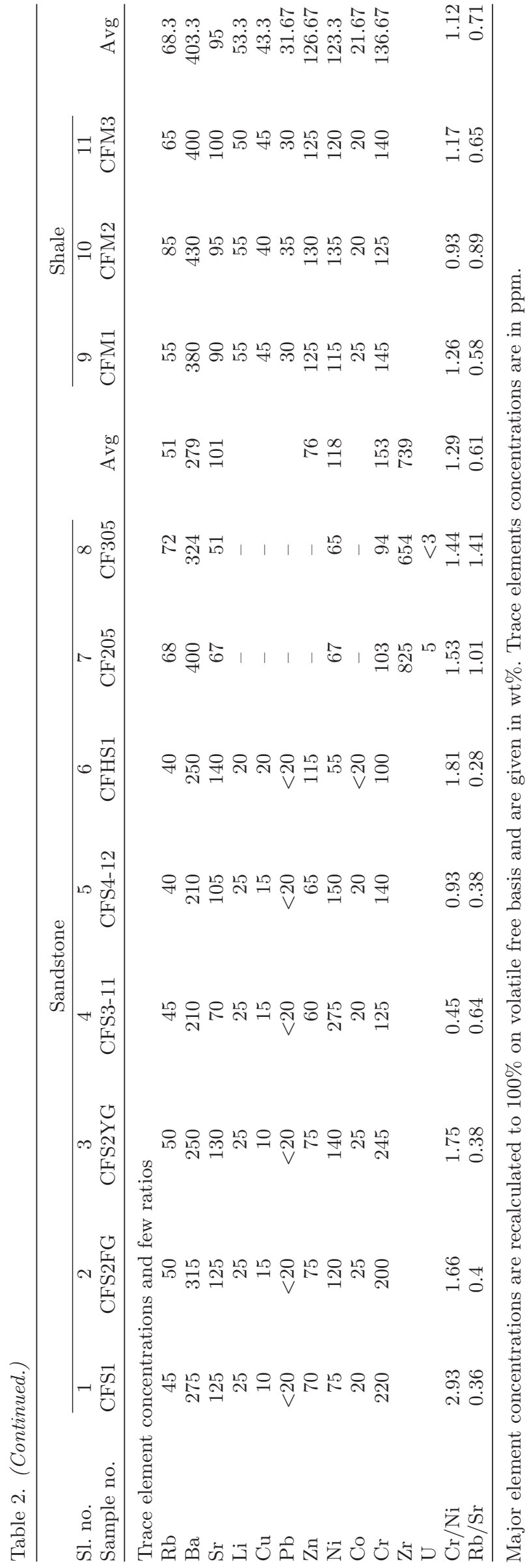

sandstones from the Wandoor outcrop, west coast of South Andaman reveal relatively higher silica content, higher $\mathrm{K}_{2} \mathrm{O} / \mathrm{Na}_{2} \mathrm{O}$ ratio, lower $\mathrm{Cr}$ and $\mathrm{Ni}$ content, higher $\mathrm{Rb} / \mathrm{Sr}$ ratios and lower CIA values, than that of the Corbyn's Cove samples with no signature of volcanic input for Wandoor samples that indicate a granite source (details will be published separately). This highlights the significant differences in compositions between Corbyn's Cove and Wandoor samples.

\subsection{Trace elements}

The range and average of eleven trace elements for sandstones and shale are presented in table 2 . $\mathrm{Cr}$ in Flysch sandstones is in the range of 94$245 \mathrm{ppm}$ (average $153 \mathrm{ppm}$ ), Ni 55-275 ppm (average $118 \mathrm{ppm}$ ) and the $\mathrm{Cr} / \mathrm{Ni}$ ratios vary from 0.45 to 2.93 (average 1.29). Cr in shale is in the range of 125-145 ppm (average $136.67 \mathrm{ppm}$ ), Ni 115$135 \mathrm{ppm}$ (average $123 \mathrm{ppm}$ ) and the $\mathrm{Cr} / \mathrm{Ni}$ ratios vary from 0.93 to 1.17 (average 1.12). The average Cr content in Andaman Flysch compares with that of NASC and PAAS whereas average $\mathrm{Ni}$ content is much higher than NASC and PAAS (table 3). Among the LILE (Rb, Sr, Pb, U, Th, Ba) and HFSE (Zr, Hf, Nb, Y, Ta), concentrations of Rb, $\mathrm{Sr}, \mathrm{Ba}$ and $\mathrm{Zr}$ are determined. The $\mathrm{Rb}$ content in Flysch sandstones varies from 40 to $72 \mathrm{ppm}$ (average $51 \mathrm{ppm}$ ) and in shale from 55 to $85 \mathrm{ppm}$ (average $68 \mathrm{ppm}$ ). The $\mathrm{Sr}$ in sandstones is in the range of $51-140 \mathrm{ppm}$ (average $101 \mathrm{ppm}$ ) and in shale it is in the range of $90-100 \mathrm{ppm}$ (average $95 \mathrm{ppm})$. Long et al. (2008) showed that the relatively high $\mathrm{Rb}$ concentrations (>40 ppm) and low $\mathrm{Rb} / \mathrm{Sr}(0.04-3.24)$ ratio are indicative of acidicintermediate igneous source that had undergone weak chemical weathering. In most cases, weathering and diagenetic processes can lead to a significant increase in $\mathrm{Rb} / \mathrm{Sr}$ ratios and high $\mathrm{Rb} / \mathrm{Sr}$ values have been interpreted as a signature of strong weathering and sedimentary recycling (McLennan et al. 1993). The $\mathrm{Rb} / \mathrm{Sr}$ value of 16 has been interpreted as reflecting intense chemical weathering (Rashid 2002). In comparison, the average $\mathrm{Rb} / \mathrm{Sr}$ values 0.61 and 0.71 in the studied sandstones and shale respectively (table 2) are lower. These ratios are higher than that of the average upper continental crust (0.32) but slightly lower than that of the average PAAS (0.80, McLennan et al. 1983). These comparisons reveal that the Flysch sandstones and shales have relatively low $\mathrm{Rb} / \mathrm{Sr}$ ratios. Concentrations of $\mathrm{Zr}$ in two sandstone samples are 825 and $654 \mathrm{ppm}$ (average 739 $\mathrm{ppm})$. The average $\mathrm{Zr}$ value is higher than the average value given for average sandstone (220 ppm) (Turekian and Wedepohl 1961). This high value could be due to potential hydraulic sorting 


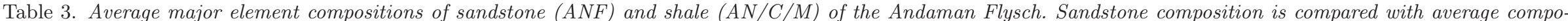

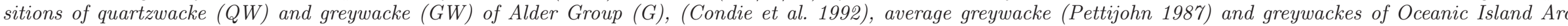

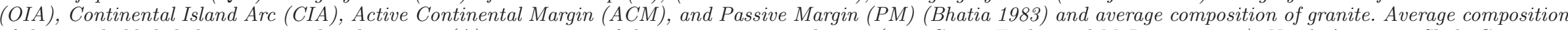

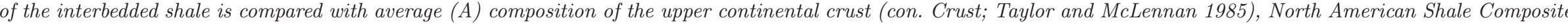
(NASC) (Gromet et al. 1984) and Post-Archean Average Shale (PAAS).

\begin{tabular}{|c|c|c|c|c|c|c|c|c|c|c|c|c|c|}
\hline & $\mathrm{ANF}$ & $\begin{array}{c}\text { QW } \\
\text { (Alder G) }\end{array}$ & $\begin{array}{c}\text { GW } \\
\text { (Alder G) }\end{array}$ & AV GW & OIA GW & CIA GW & ACM GW & PM GW & $\begin{array}{l}\text { AV Cont. } \\
\text { crust }\end{array}$ & Granite & $\mathrm{AN} / \mathrm{C} / \mathrm{M}$ & PAAS & NASC \\
\hline \multicolumn{14}{|c|}{ Major elements } \\
\hline $\mathrm{SiO}_{2}$ & 70.75 & 70.05 & 60.59 & 66.7 & 59 & 71 & 74 & 82 & 61.9 & 73.3 & 59.63 & 62.8 & 64.8 \\
\hline $\mathrm{TiO}_{2}$ & 1.01 & 0.72 & 0.94 & 0.6 & 1.06 & 0.64 & 0.46 & 0.49 & 0.8 & 0.28 & 1.23 & 1 & 0.78 \\
\hline $\mathrm{Al}_{2} \mathrm{O}_{3}$ & 14.52 & 13.08 & 16.36 & 13.5 & 17 & 14 & 13 & 8 & 15.6 & 13.5 & 20.29 & 18.9 & 16.9 \\
\hline $\mathrm{Fe}_{2} \mathrm{O}_{3}$ & 4.1 & $* 6.2$ & $* 8.44$ & 1.6 & & & & & 2.6 & 2.3 & 4.75 & 6.5 & 5.7 \\
\hline $\mathrm{FeO}$ & 1.95 & & & 3.5 & & & & & 3.9 & & 4.48 & & \\
\hline $\mathrm{MgO}$ & 2.44 & 2.45 & 2.55 & 2.1 & & & & & 3.1 & 0.42 & 3.75 & 2.2 & 2.85 \\
\hline $\mathrm{MnO}$ & 0.08 & & & & & & & & & & 0.11 & 0.11 & 0.06 \\
\hline $\mathrm{CaO}$ & 0.41 & 0.26 & 2.66 & 2.5 & 5.8 & 2.7 & 2.5 & 1.9 & 5.7 & 1.3 & 0.44 & 1.3 & 3.56 \\
\hline $\mathrm{Na}_{2} \mathrm{O}$ & 1.83 & 1.69 & 3.23 & 2.9 & 4.1 & 3.1 & 2.8 & 1.1 & 3.1 & 4.8 & 1.42 & 1.2 & 1.15 \\
\hline $\mathrm{K}_{2} \mathrm{O}$ & 2.11 & 3.6 & 2.48 & 2 & 1.1 & 1.9 & 2.9 & 1.7 & 2.9 & 0.08 & 3.71 & 3.7 & 3.99 \\
\hline $\mathrm{P}_{2} \mathrm{O}_{5}$ & 0.13 & 0.11 & 0.34 & & & & & & & & 0.13 & 0.16 & 0.11 \\
\hline \multicolumn{14}{|c|}{ Trace elements } \\
\hline $\mathrm{Rb}$ & 51 & 117 & 88 & & & & & & & & 68.3 & 160 & 125 \\
\hline $\mathrm{Ba}$ & 279 & 678 & 804 & & 370 & 444 & 522 & 253 & & & 403.3 & & 636 \\
\hline $\mathrm{Sr}$ & 101 & 114 & 384 & & & & & & & & 95 & 200 & 142 \\
\hline $\mathrm{Li}$ & 24.16 & & & & & & & & & & 53.3 & & \\
\hline $\mathrm{Cu}$ & 14.17 & & & & & & & & & & 43.3 & & \\
\hline $\mathrm{Pb}$ & $<20$ & & & & 7 & 15 & 24 & 16 & & & 31.67 & 20 & \\
\hline $\mathrm{Zn}$ & 76 & & & & & & & & & & 126.67 & & \\
\hline $\mathrm{Ni}$ & 118 & 26 & 56 & & 31 & 13 & 10 & 8 & & & 123.3 & 55 & 58 \\
\hline $\mathrm{Co}$ & 22 & 11 & 24 & & & & & & & & 21.67 & & 25.7 \\
\hline $\mathrm{Cr}$ & 153 & 72 & 105 & & 37 & 51 & 26 & 39 & & & 136.67 & 110 & 124.5 \\
\hline $\mathrm{Zr}$ & 739 & 194 & 172 & & 96 & 229 & 179 & 298 & & & & 210 & 200 \\
\hline $\mathrm{Cr} / \mathrm{Ni}$ & 1.30 & 2.77 & 1.88 & & 1.19 & 3.92 & 2.60 & 4.88 & & & 1.11 & 2 & 2.15 \\
\hline $\mathrm{n}$ & 8 & 8 & 17 & & & & & & & & & & \\
\hline
\end{tabular}


and grain-size effects (Garzanti et al. 2013b). Similar high values of $\mathrm{Zr}$ in sandstones are attributed to the presence of granite-rich rocks at the source (Banerjee and Banerjee 2010).

\section{Discussion}

\subsection{Geochemical classification}

Condie et al. (1992) proposed that although greywackes and quartzwackes show compositional overlap, they can be differentiated. Quartzwackes range from $65-75 \mathrm{wt} \% \quad \mathrm{SiO}_{2}$ content, whereas greywackes range from 50-70 wt\%. Quartzwackes tend to be lower in $\mathrm{CaO}(<1 \mathrm{wt} \%), \mathrm{Na}_{2} \mathrm{O}(<2 \mathrm{wt} \%)$ and $\mathrm{P}_{2} \mathrm{O}_{5}(<0.1$ wt $\%)$ than greywackes. When compared, the average composition of the Flysch sandstones (table 3 ) reflects relatively higher silica and lower $\mathrm{MgO}, \mathrm{Na}_{2} \mathrm{O}, \mathrm{CaO}$ and $\mathrm{K}_{2} \mathrm{O}$ contents than average greywackes and compared to that of quartzwacke sandstones (Condie et al. 1992). On the basis of quartz content, $\mathrm{K}_{2} \mathrm{O} / \mathrm{Na}_{2} \mathrm{O}$ ratio and $\mathrm{SiO}_{2}$ percentage, Crook (1974) classified the sandstones into quartz-rich, quartz-intermediate and quartz-poor types, stating that they represent different tectonic settings. The Flysch sandstones have intermediate quartz content, average $\mathrm{SiO}_{2}\left(70.75\right.$ wt\%) and $\mathrm{K}_{2} \mathrm{O} / \mathrm{Na}_{2} \mathrm{O}$ ratios lower to marginally higher than 1 (average 1.08), reflecting that the sandstones are predominantly quartzintermediate type. The quartzwacke geochemical classification of the studied sandstones is in good agreement with petrographic study.

\subsection{Source rock}

\subsubsection{Petrographic data}

In the quartzwacke sandstones of the Andaman Flysch, framework detritus are dominated by monocrystalline quartz and subordinate polycrystalline quartz. The dominance of stable monocrystalline quartz $(\mathrm{Qm})$ over unstable polycrystalline quartz suggests that even though the turbidite sandstones are overall immature, they have recycled sedimentary sources. Rounded grains, quartz with abraded overgrowth and rounded zircons indicate a recycled (sedimentary) source. The polycrystalline quartz with a few (up to five) large subgrains showing interlocking grain contacts and grain with graphic texture are sourced from granite; those having more than five subgrains of unequal sizes and shapes and penetrative subgrain contacts were possibly sourced from low to medium-grade metamorphic rocks and those with numerous small and flattened (stretched) subgrains with strongly sutured grain contacts, indicate highgrade metamorphic source (Garzanti and Vezzoli
2003). Quartz-mica schists were invariably derived from medium-grade metamorphic rocks. Other components include a minor amount of weathered basalt, long and short prismatic zircon, and euhedral plagioclase, indicative of volcanic arc and ophiolite sources.

\subsubsection{Geochemical data}

The quartzwacke sandstones have silica content (range 68.53-73.91 wt\% $\mathrm{SiO}_{2}$; average $70.75 \mathrm{wt} \%$ $\mathrm{SiO}_{2}$ ) that reflects the restricted range of $\mathrm{SiO}_{2}$ variation and corresponds to the composition of average granite. Following Armstrong-Altrin (2009), classification of volcanic rocks by Le Bas et al. (1986) based on $\mathrm{SiO}_{2}$ content, is used in this study to correlate the igneous parentage for the sandstones and a felsic source rock composition seems to be the best fit igneous parentage. Provenance lithology for these sandstones can also be depicted on a $\mathrm{CaO}-\mathrm{Na}_{2} \mathrm{O}-\mathrm{K}_{2} \mathrm{O}$ ternary diagram of Le Maître (1976) on which the average composition of andesite (A), dacite (D), granodiorite (Gr) and granite $(\mathrm{G})$ are plotted (figure 4). Majority of the individual analyses and the average value for the sandstone in figure 4 are plotted close to average composition of granite. Two analyses showing very low $(0.06 \mathrm{wt} \%)$ and high $(5.99 \mathrm{wt} \%) \mathrm{CaO}$ contents plot away from the average granite. Also plotting of data on the $\mathrm{Al}_{2} \mathrm{O}_{3} / \mathrm{TiO}_{2}$ vs. $\mathrm{SiO}_{2}$ diagram (Le Bas et al. 1986) show sandstone compositions fall in the field of felsic rock while that of shale falls in the intermediate field (figure 5). The $\mathrm{Al}_{2} \mathrm{O}_{3}$ and $\mathrm{TiO}_{2}$ serve as excellent indicators of terrigeneous input, and are therefore relatively enriched in

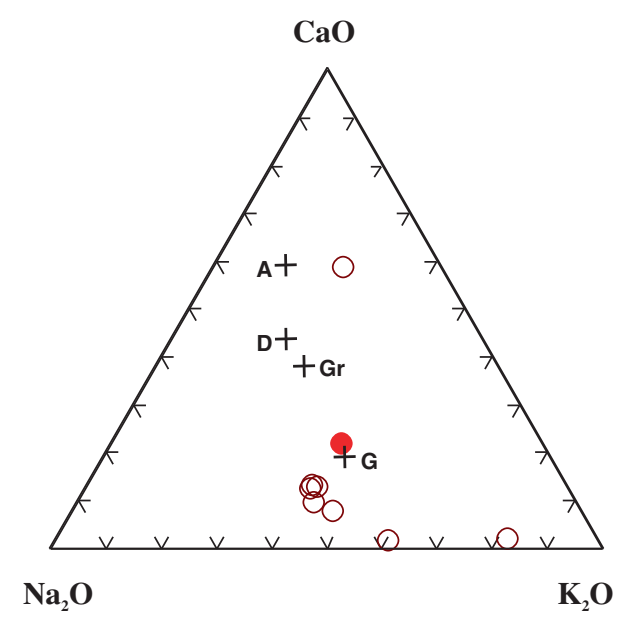

Figure 4. $\mathrm{CaO}-\mathrm{Na}_{2} \mathrm{O}-\mathrm{K}_{2} \mathrm{O}$ diagram showing average composition of andesite (A), dacite (D), granodiorite $(\mathrm{Gr})$ and granite (G), after Le Maitre (1976). The individual (open circle) and average (solid circle) compositions of turbidite sandstones Corbyn's Cove, South Andaman Island are plotted near granite $(+)$. Two analyses with very high and very low $\mathrm{CaO}$ contents plot away from the granite field. Triangle represents shale and circle represents sandstone. 


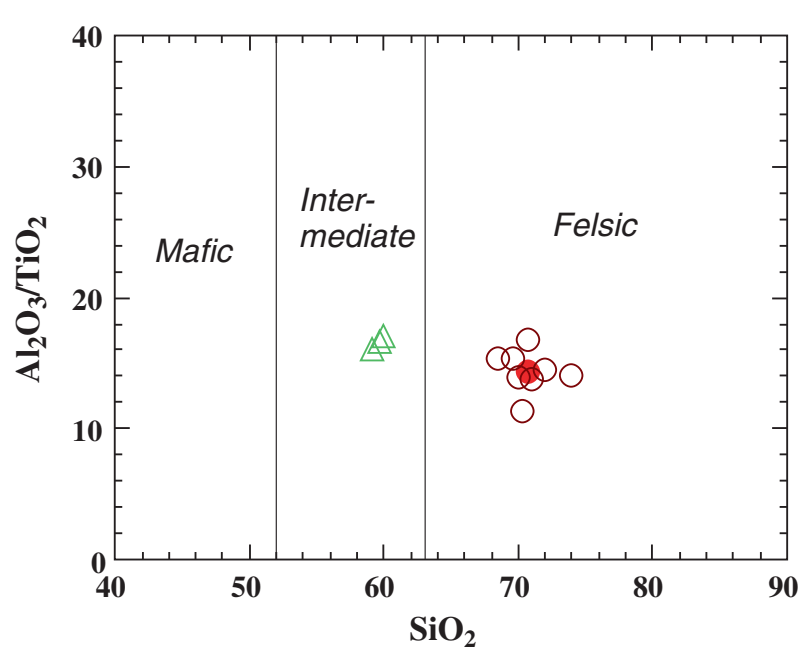

Figure 5. The $\mathrm{Al}_{2} \mathrm{O}_{3} / \mathrm{TiO}_{2}$ vs. $\mathrm{SiO}_{2}$ relationship for sandstone-shale turbidites. The fields are from Le Bas et al. (1986). Note the sandstone compositions fall in the felsic and shale in the intermediate field. Symbols are as in figure 4.

sediments deposited adjacent to, and derived from eroding continent or island arcs (Murray 1994). Statistical summary of the composition of different types of igneous rocks by Le Maitre (1976) showed that mafic rocks typically have $\mathrm{Al}_{2} \mathrm{O}_{3} / \mathrm{TiO}_{2}$ values $<14$. Further, this ratio ranges from 3 to 8 for mafic igneous rocks, from 8 to 21 for rocks of intermediate composition and from 21 to 70 for felsic igneous rocks (Chakrabarti et al. 2009). The $\mathrm{Al}_{2} \mathrm{O}_{3} / \mathrm{TiO}_{2}$ values in our study are in the range of 11.27-17.00 (average of 14.36) for sandstone and 16.55 (average) for shale (table 2), suggesting intermediate igneous rocks were predominant source rocks. This geochemical constraints is consistent with petrographic evidence of the dominance of quartz, alkali feldspars over plagioclase, schistose rock fragments and rarity of volcanic rock fragments. Except a slightly lower $\mathrm{CaO}$ and $\mathrm{Na}_{2} \mathrm{O}$ content, the average major element composition of the interbedded shale compares with that of the upper continental crust composed of granitoid (table 3 ). The average composition of shale also compares to that of the shales and pelites of the Mesoproterozoic Chakrata Formation for which derivation of detritus from granite dominated upper continental crust was inferred (Rashid 2002; Raza et al. 2002). The $\mathrm{Rb} / \mathrm{Sr}$ ratio is a measure of determining the intensity of source-rock weathering and sedimentary recycling and is also considered useful for provenance analysis (McLennan et al. 1993; Long et al. 2008). The range and average concentrations of $\mathrm{Rb}$ and $\mathrm{Sr}$ and their ratios (table 2) in sandstones and shale when compared with that of the Lower Paleozoic meta argillaceous rocks of the Chinese Altai (Long et al. 2008), indicate derivation of detritus from felsic-intermediate igneous source. This interpretation, based on trace element, is consistent with that inferred from the major element and the framework compositions.

On the other hand, the $\mathrm{Cr}$ and $\mathrm{Ni}$ contents and their ratios in sandstones and shale indicate presence of mafic/ultramafic rocks at the source (Hiscott 1984; Wrafter and Graham 1989; Garver et al. 1996). In ultramafic rocks, $\mathrm{Cr} / \mathrm{Ni}$ ratio is 1.6 (cf. Garver et al. 1996). Background values of $\mathrm{Cr}$ and $\mathrm{Ni}$ in shale (NACS) are estimated to be 105 and $60 \mathrm{ppm}$ respectively (Gromet et al. 1984). Garver et al. (1996) considered elevated values of $\mathrm{Cr}(>150 \mathrm{ppm}), \mathrm{Ni}(>100 \mathrm{ppm})$ and a $\mathrm{Cr} / \mathrm{Ni}$ ratio between 1.3 and 1.5 are diagnostic of ultramafic rocks in the source region. The $\mathrm{Cr}$ and $\mathrm{Ni}$ concentrations in the studied samples are higher than the background values but are lower than the value considered indicative of ultramafic source rocks. Wrafter and Graham (1989) stated that the high $\mathrm{Ti}(>5000 \mathrm{ppm})$ and $\mathrm{Fe}(>8 \mathrm{wt} \% \mathrm{FeO})$, low $\mathrm{Mg}(\sim 4$ to 5 wt\% $\mathrm{MgO}), \mathrm{Cr}(\equiv 100 \mathrm{ppm})$ and $\mathrm{Ni}$ $(\equiv<100 \mathrm{ppm})$ indicate contribution from a mafic source whereas ultramafic source is indicated by high $\mathrm{Mg}(>8 \mathrm{wt} \% \mathrm{MgO}$ ) and higher $\mathrm{Cr}$ and $\mathrm{Ni}$ (>500 and $>200 \mathrm{ppm}$, respectively). In comparison to these values, our data (average $\mathrm{Cr} / \mathrm{Ni}$ ratio 1.29 and $\mathrm{MgO} 2.44 \mathrm{wt} \%$ for sandstone and average $\mathrm{Cr} / \mathrm{Ni}$ ratio 1.12 and $\mathrm{MgO} 3.75 \mathrm{wt} \%$ for associated shale, table 2) suggest that ultramafic rocks were hardly present and the mafic rocks were present, but not widespread, at the source region. Allen et al. (2008) suggested a subordinate contribution from mafic volcanic rocks in the Flysch sandstones.

\subsection{Provenance terrane}

Dickinson et al. (1983) classified three main categories of provenance terranes. Recently Garzanti et al. (2007) classified five primary categories; magmatic arc, ophiolite, axial belt, continental block and clastic wedge sediment provenances that accommodate more variants of tectonic settings and clear many complexities of provenance study. Continental blocks (stable craton and uplifted basement), magmatic arcs and recycled orogens are included in Dickinson's classification. The corresponding tectonic settings are continental interior (stable craton), rift shoulder or transform rupture (uplifted basement), island arc or continental arc (magmatic arcs) and subduction complexes or foldthrust belts (recycled orogen) respectively. Within recycled orogen, sediment sources are sedimentary, meta-sedimentary and volcano-plutonic igneous rocks exposed to erosion by orogenic uplift of fold belts and thrust sheets during continental collisional events (Dickinson et al. 1983). A recycled 
orogenic provenance has been suggested for the quartzwacke sandstones of the Tonto Basin, Central Arizona (Condie et al. 1992). The studied geochemical and petrographic proxies together suggest a dual provenance consisting of a recycled orogen and a volcanic arc (continental block and magmatic arc provenances of Garzanti 2007) for the turbidites with predominant input of detritus from the recycled orogen consisting of older continental crust (McLennan et al. 1990). This type of source terrane as indicated by paleocurrent direction must have been located to the north and northeast of the study area. The eastern and northeastern continental region of Myanmar, where Precambrian to late Paleozoic, intermediate to felsic igneous rocks of the Shan-Thai Block and metamorphic rocks of the Mogok metamorphic belt and the associated sedimentary rocks exposed, possibly the most likely provenance. The mafic source may be the mafic volcanic rocks of arc massif that existed and extended all along the western side of the Myanmar-Malaya-Thai peninsula during late Cretaceous subduction events (Mitchell 1993). Allen et al. (2008) based on sandstone petrography and Sm-Nd isotope study also suggested that the source for the Flysch sandstones is likely to be the northeastern Myanmar continental region and a subordinate source is likely that of the volcanic arc in the east Myanmar.

\subsection{Tectonic setting}

The sandstone-dominated turbidites of the South Andaman Flysch represent a first-order indication of an active margin tectonic setting characterized by sand-rich turbidites (Mattern 2005). Sediment provenances and their corresponding tectonic settings have shown that the recycled orogenic provenance, suggested for the studied turbidites, corresponds to an active continental margin tectonic setting. Dickinson and Suczek (1979) and several subsequent studies used framework mineralogy to relate sandstone compositions to various tectonic settings (Garzanti et al. 2007). Roser and Korsch (1986) used a discrimination diagram $\left(\mathrm{K}_{2} \mathrm{O} / \mathrm{Na}_{2} \mathrm{O}\right.$ vs. $\mathrm{SiO}_{2}$ ) to determine the tectonic setting of the sandstone-mudstone suites that shows $\mathrm{SiO}_{2}$ content and $\mathrm{K}_{2} \mathrm{O} / \mathrm{Na}_{2} \mathrm{O}$ values increase from volcanic arc to active continental margin to passive margin settings. Bhatia (1983) also discriminated tectonic settings of Paleozoic greywacke sandstones on the basis of major element data. These are oceanic island arc (OIA), continental island arc (CIA), active continental margin (ACM) and passive margin (PM) settings (table 3). Later studies (Armstrong-Altrin and Verma 2005; Verma and Armstrong-Altrin 2013) have questioned the usefulness of the previous tectonic discrimination diagrams and interpreted that the diagrams of Bhatia do not work reliably and the diagram of Roser and Korsch (1986) performs somewhat better with a $32-62 \%$ success rate. Examination of current literature has, however, revealed that the diagram of Roser and Korsch is used widely with success. In $\mathrm{K}_{2} \mathrm{O} / \mathrm{Na}_{2} \mathrm{O}$ vs. $\mathrm{SiO}_{2}$ diagram, both studied sandstones and shales plot in the field of active continental margin tectonic setting (figure 6). The $\mathrm{SiO}_{2} / \mathrm{Al}_{2} \mathrm{O}_{3}$ ratio (average 4.91) in Flysch sandstone is similar to many ancient turbidites of active margin and continental arc tectonic settings (Maynard et al. 1982; McLennan et al. 1990). The major element compositions of the interbedded shale resemble to that of the mudstone from the Chinese Altai, inferred to have been deposited on continental arc basin (Long et al. 2008). Bhatia (1983) showed that the average composition of the active continental margin type sandstones is characterized by almost equal amounts of $\mathrm{K}_{2} \mathrm{O}$ and $\mathrm{Na}_{2} \mathrm{O}$ and the bulk composition is similar to that of the crystalline basement of the upper continental crust. Similar observations with respect to $\mathrm{K}_{2} \mathrm{O}$ and $\mathrm{Na}_{2} \mathrm{O}$ abundances in the studied sandstones again support an active continental margin tectonic setting. The sandstone compositions on the $\mathrm{K}_{2} \mathrm{O} / \mathrm{Na}_{2} \mathrm{O}$ diagram of Crook (1974) (not shown) plot in the quartzintermediate field and quartz-rich field closer to quartz-intermediate boundary, suggesting that an active continental margin is the most likely tectonic setting. The studied geochemical signatures and the regional tectonic scenario of northern and northeastern Myanmar, already discussed

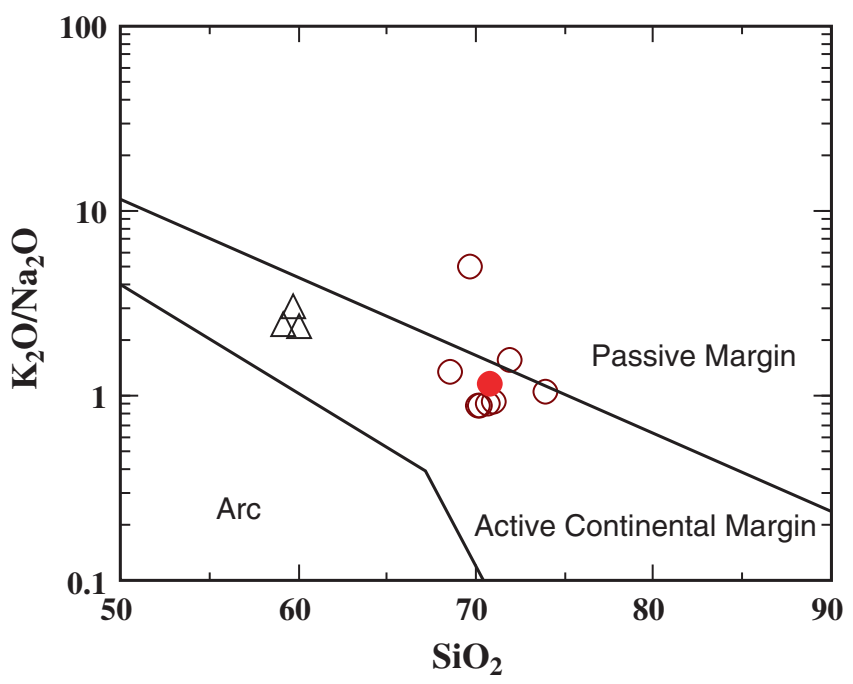

Figure 6. $\mathrm{K}_{2} \mathrm{O} / \mathrm{Na}_{2} \mathrm{O}-\mathrm{SiO}_{2}$ diagram (after Roser and Korsch 1986) showing plots of sandstones and shales that fall in active continental margin (ACM) field including the average one (solid circle) and one close to the boundary line separating the PM and ACM field. Symbols are as in figure 4. 
as active continental margin, support the above contention.

The previous studies described the Andaman Flysch as a forearc basin deposit, adjacent to the Andaman accretionary arc (Chakraborty and Pal 2001; Pal et al. 2003). Curray (2005) questioned that if the Flysch sandstones are forearc deposits, the source of the 3000-m thick Flysch sediments could hardly be from islands on the outer arc ridge that are very limited in size and instead, suggested that the Andaman Flysch represents, at least in part, Bengal Fan sediments. In this regard, it may also be important to note that arc-derived sands and sandstones, deposited in associated forearc/interarc basin, share characteristics of low quartz content and a high proportion of volcanic lithic grains derived from a volcano capping the arc massif (Maynard et al. 1982; McLennan et al. 1990; Tucker 2001; Garzanti et al. 2007). Therefore, the volcanic lithic poor, quartzose sandstones of the Andaman Flysch with a minor geochemical signature of arc input, do not suggest deposition in a forearc basin. Quartzolithic/feldspatic turbidite sandstones derived from recycled orogen, similar to those studied here, occur in Nias and Makran accretionary wedges (Moore 1979; Critelli et al. 1990). Critelli (1993) mentioned that the quartzose sandstones in deep marine fan are generally produced by long distance transport by the turbidity currents from a provenance in a tectonic domain not directly related to the trench. Petrofacies analysis of forearc basin turbidite sandstones, Great Valley Group, northern and central California, has shown significant presence of volcanic sands in sandstones derived from magmatic arc (Ingersoll 1983) as also observed for forearc basin sandstones in Circum-Pacific subduction complexes. Therefore, the studied Flysch turbidites which formed during the waning stage of arc volcanism, were possibly deposited as part of a submarine fan on an open ocean floor environment within an active continental margin tectonic setting associated with recycled orogenic province, before being incorporated into the outer arc of the Andaman accretionary complex. Thus, the inferred tectonic setting was not directly related to Andaman-Java trench. Bandopadhyay (2012) suggested that the Andaman Flysch was deposited beyond the influence of forearc sedimentation whereas volcanic arc signatures are very clear in rocks of the underlying volcaniclastic turbidite sandstones of the Namunagar Formation (Bandopadhyay 2005), implying significant differences in respect of their provenance. The deposition of Namunagar Formation in small fault-controlled basins within the trench-slope setting has been inferred (Karunakaran et al. 1968; Chakraborty et al. 1999).

\subsection{Paleoweathering}

The Chemical Index of Alteration (CIA) values reflect the intensity of chemical weathering in the source region (Nesbitt and Young 1982). CIA values of Phanerozoic shales generally range from 70-75, indicating moderate chemical weathering and the formation of muscovite, illite and smectite during weathering, whereas more intense weathering results in formation of kaolinite and gibbsite with CIA values approaching 100 (Nesbitt and Young 1984). Fedo et al. (1995) mentioned that the CIA value of 50-60 indicates an incipient weathering, 60-80 an intermediate weathering and CIA $>80$ extreme weathering. Values of $\sim 80$ are generally considered as moderate weathering (Young and Nesbitt 1998). The weathering history of igneous rocks and the source for various sedimentary rocks have been examined by using $\mathrm{A}-\mathrm{CN}-\mathrm{K}$ $\left(\mathrm{A}=\mathrm{Al}_{2} \mathrm{O}_{3}, \mathrm{CN}=\mathrm{CaO}+\mathrm{Na}_{2} \mathrm{O}, \mathrm{K}=\mathrm{K}_{2} \mathrm{O}\right)$ triangular diagram (Nesbitt and Young 1982). The diagram (figure 7) also displays the compositional trends of igneous rocks during initial stage of weathering that are almost parallel to $\mathrm{A}-\mathrm{CN}$ line from their respective fresh unweathered points. CIA values for Flysch sandstones and for interbedded shale are: range 72-85 and average 77 and 78.1278.67 , average 78.46 , respectively. These values are slightly higher than those of average shale estimates (CIA for pelites $=70-75$ ). The CIA values suggest a moderate range of chemical weathering at

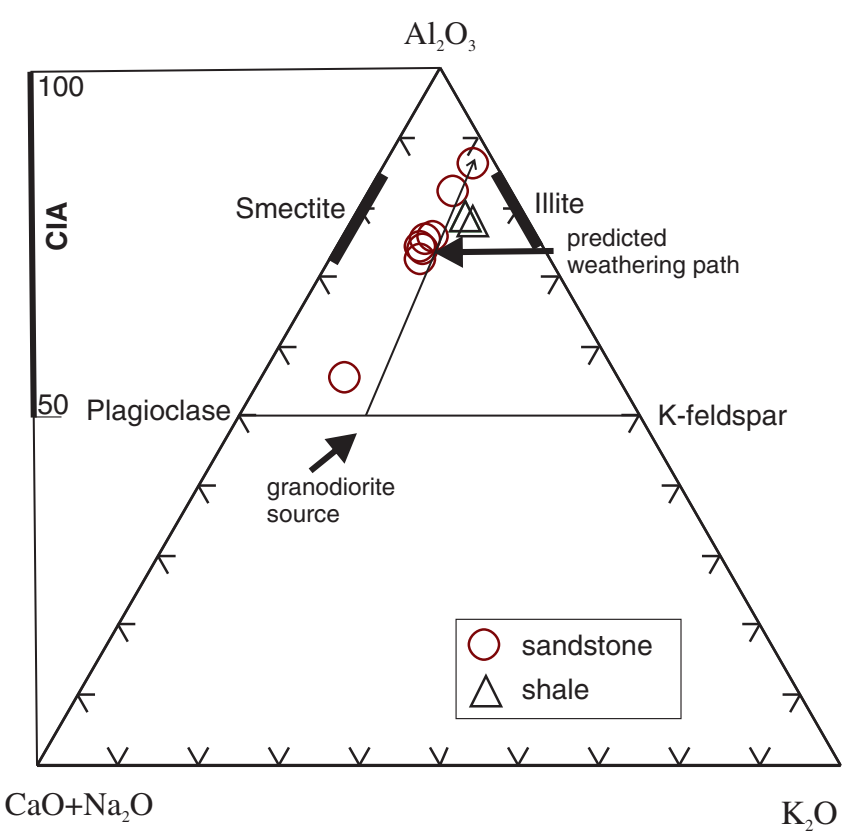

Figure 7. A-CN-K $\left(\mathrm{Al}_{2} \mathrm{O}_{3}-\mathrm{CaO}+\mathrm{Na}_{2} \mathrm{O}-\mathrm{K}_{2} \mathrm{O}\right)$ ternary diagram (after Nesbitt and Young 1982) showing plots of turbidite sandstones and shales cluster towards Illite field and show predicted weathering trend meets the granitegranodiorite composition. $\mathrm{A}=\mathrm{Al}_{2} \mathrm{O}_{3}, \mathrm{CN}=\mathrm{CaO}+\mathrm{Na}_{2} \mathrm{O}, \mathrm{K}=$ $\mathrm{K}_{2} \mathrm{O}, \mathrm{CaO}=\mathrm{CaO}$ in silicate phase. 
the provenance and the similar values for sandstone and shale indicate the same intensity of weathering. The $\mathrm{Rb} / \mathrm{Sr}$ ratio has been used to measure the intensity of weathering at the source region (Rashid 2002; Long et al. 2008). For the Flysch sandstone, it is 0.61 and for shale, it is 0.71 which in comparison appears low. The Rb concentration in both of them is $\geq 40 \mathrm{ppm}$ considered to be high (Long et al. 2008). Therefore, the relatively high Rb concentration and low $\mathrm{Rb} / \mathrm{Sr}$ ratio instead imply weak to moderate chemical weathering at the source (Long et al. 2008). Intensely weathered sediments show strong depletion of $\mathrm{CaO}, \mathrm{Na}_{2} \mathrm{O}$ and $\mathrm{Sr}$ (Absar et al. 2009). The values of $\mathrm{CaO}, \mathrm{Na}_{2} \mathrm{O}$ and $\mathrm{Sr}$ in studied turbidites, in comparison to those given by Absar et al. (2009) are higher and thus suggest moderate weathering. However, depletion in $\mathrm{Al}_{2} \mathrm{O}_{3}$ and enrichment in $\mathrm{SiO}_{2}$ relative to the average composition of crust and NASC (table 3 ) were probably due to sedimentary sorting and loss of clays $\left(\mathrm{Al}_{2} \mathrm{O}_{3}\right.$-rich, $\mathrm{SiO}_{2}$-poor $)$ and retention of quartz $\left(\mathrm{Al}_{2} \mathrm{O}_{3}\right.$-poor, $\mathrm{SiO}_{2}$-rich). The $\mathrm{Al}_{2} \mathrm{O}_{3}$ and $\mathrm{TiO}_{2}$ show positive correlation in both sandstone and shale and the regression coefficient $(r=0.57)$ in comparison to strong positive correlation $(r=0.86$; Absar et al. 2009) indicative of intense weathering, suggests a moderately strong correlation and in turn moderate range of weathering at the provenance. Young and Nesbitt (1998) showed that the moderate weathering is also indicated where data plots at about $70 \% \mathrm{Al}_{2} \mathrm{O}_{3}$ on the $\mathrm{Al}_{2} \mathrm{O}_{3}-\left(\mathrm{CaO}+\mathrm{Na}_{2} \mathrm{O}\right)-$ $\mathrm{K}_{2} \mathrm{O}$ triangle. We find that majority of the sandstone samples plots at about $74-75 \% \quad \mathrm{Al}_{2} \mathrm{O}_{3}$ indicating weathering at the provenance was just above the moderate range. The two sandstones and the shale samples plot at a slightly higher value indicate lower side of the intense range of weathering. Combining all these proxies, it is most likely that the Flysch sandstone was by and large subjected to moderate range of weathering.

With regard to paleoclimate and relief, it may be inferred that the sources for the sediments were exposed to climates similar to those representatives of the average Phanerozoic. The studied samples with a moderate range of CIA values cluster close to illite field in $\mathrm{A}-\mathrm{CN}-\mathrm{K}$ diagram and also plot along the granite-granodiorite weathering trend (figure 7). As the degree of weathering is a function chiefly of climate and rates of tectonic uplift (Wronkiewicz and Condie 1987), increased chemical weathering may reflect the decrease in tectonic activity and/or the change of climate towards warm and humid conditions favouring enhanced chemical weathering in the source region (Jacobson et al. 2003). Therefore, weathering indices of sedimentary rocks can provide useful information about the source area tectonic activity and climatic conditions. A moderate range of weathering inferred in this study, therefore indicate that the source region was a moderate relief and tectonically active terrane exposed to warm and humid paleoclimate during weathering. This is consistent with regional geology of the study area. The plots for Andaman Flysch on $\mathrm{Al}_{2} \mathrm{O}_{3}-\left(\mathrm{CaO}+\mathrm{Na}_{2} \mathrm{O}\right)-$ $\mathrm{K}_{2} \mathrm{O}$ (ACN) ternary diagram shows that they fall away from the feldspar joining line indicating selective removal of $\mathrm{Ca}, \mathrm{Na}$ and enrichment of $\mathrm{Al}_{2} \mathrm{O}_{3}$ during weathering of the source region (figure 7).

\section{Conclusions}

This study presents the previously undocumented major and trace element compositions of the Flysch turbidites exposed along the east coast of South Andaman and deciphers the petrogenesis of the turbidite sandstones using geochemistry reflecting quartzwacke composition of the sandstones, which received detritus from granitoid, metasedimentary and sedimentary rocks of upper continental crust and a minor amount from mafic volcanic arc, and indicates a recycled orogenic provenance. This geochemical approaches complement the information derived from petrographic study. The tectonic discrimination diagram, key element ratios and the range and average compositions of major and trace elements together with petrographic data collectively indicate that an active continental margin and associated magmatic arc appear as a best-fit tectonic settings for the provenance region of the studied Andaman Flysch. Such a provenance was likely made up of granitoid rocks with subordinate sedimentary and metamorphic rocks and arc massif. Such lithologies and palaeocurrent directions suggest that the Shan-Thai block of the northeastern Myanmar continental region as the dominant source terrane. The mafic volcanic arc of the Shan-Thai-Malaya continents also contributed detritus to the turbidites.

\section{Acknowledgements}

The paper has benefitted from the detailed and constructive criticism offered by the reviewers of the journal, who preferred to remain anonymous. Useful comments of Prof. Garzanti for the revised manuscript helped to improve the text. This research article is an outcome of a book writing project sponsored by DST, Govt. of India to PCB under USERS scheme (file no. SB/UR/14/2012). The logistic support was provided by the Department of Geology, University of Calcutta. The authors thankfully acknowledge the financial and logistic supports. Various technical helps, during 
the preparation of the manuscript, received from Mr Debaditya Bandopadhyay and in subsequent stages, from Miss Sukanya Chaudhury and Miss Soumi Chatterjee, research scholars, are acknowledged with affection and appreciation.

\section{References}

Absar N, Raza M, Roy M, Naqvi S M and Roy A K 2009 Composition and weathering conditions of Paleoproterozoic upper crust of Bundelkhand craton, central India: Records from geochemistry of clastic sediments of $1.9 \mathrm{Ga}$ Gwalior Group; Precamb. Res. 168 313-329.

Acharyya S K 1997 Stratigraphy and tectonic history reconstruction of the Indo-Burma-Andaman mobile belt; Indian J. Geol. 69 211-234.

Acharyya S K 2007 Collisional emplacement history of the Naga-Andaman ophiolites and the position of the eastern Indian suture; J. Asian Earth Sci. 29 239-242.

Allen R, Carter A, Najman Y, Bandopadhyay P C, Chapman Bickle M J, Garzanti E, Vezzoli G, Andò G, Foster G L and Gerring C 2008 New constraints on the sedimentation and uplift history of the Andaman-Nicobar accretionary prism, South Andaman Island. Formation and application of sedimentary records in arc collision zone (eds) Draut A, Clift P D and Scholl D W, Geol. Soc. Am. Spec. Publ. 436 223-256.

Armstrong-Altrin J S 2009 Provenance of sands from Cazones, Acapulco, and Bahia Kino beaches, Mexico; Revista Mexicana de Ciencias Geologicas 26 764-782.

Armstrong-Altrin J S and Verma S P 2005 Critical evaluation of six tectonic setting discrimination diagrams using geochemical data of Neogene sediments from known tectonic settings; Sedim. Geol. 177 115-129.

Bandopadhyay P C 2005 Discovery of abundant pyroclasts in Eocene Namunagarh Grit, South Andaman: Evidence for arc volcanism and subduction during the Palaeogene in the Andaman area; J. Asian Earth Sci. 25 97-107.

Bandopadhyay P C 2012 Re-interpretation of the age and depositional environment of the Paleogene turbidites in Andaman and Nicobar islands, Western Sunda Arc; J. Asian Earth Sci. 45 126-137.

Bandopadhyay P C and Ghosh M 1998 Facies, petrology and depositional environment of the Tertiary sedimentary rocks around Port Blair, South Andaman; J. Geol. Soc. India 52 53-66.

Bandopadhyay P C, Chakrabarti U, Mohapatra N R and Roy A 2008 New field evidence of co-seismic uplift during the December 2004 earthquake, North Andaman Island; J. Geol. Soc. India 72 871-874.

Bandopadhyay P C, Chakrabarti U and Roy A 2009 First report of trace fossils from Palaeogene succession (Namunagarh Grit) of Andaman and Nicobar Islands; J. Geol. Soc. India 73 261-267.

Bandopadhyay P C, Ghosh B and Limonta M 2014 A reappraisal of the eruptive history and recent (1991-2009) volcanic eruptions of Barren Island, Andaman Sea; Episode 37 1-14.

Banerjee A and Banerjee D M 2010 Modal analysis and geochemistry of two sandstones of the Bhander Group (late Neo-proterozoic) in parts of the central Indian Vindhyan basin and their bearing on provenance and tectonics; J. Earth Syst. Sci. 119 825-839.

Bhat M I and Ghosh S K 2001 Geochemistry of 2.51 Ga old Rampur Group pelites, western Himalaya: Implications for their provenance and weathering; Precamb. Res. 108 $1-16$.

Bhatia M R 1983 Plate tectonics and geochemical composition of sandstones; J. Geol. 91 611-627.

Bhatia M R and Crook K A W 1986 Trace element characteristics of greywacke and tectonic setting discrimination of sedimentary basins; Contrib. Mineral. Petrol. 92 $181-193$.

Chakrabarti G, Shome D, Blanca B and Sinha S 2009 Provenance and weathering history of mesoproterozoic clastic sedimentary rocks from the basal Gulcheru Formation, Cuddapah Basin; J. Geol. Soc. India 74 119-130.

Chakraborty P P and Pal T 2001 Anatomy of a forearc submarine fan: Upper Eocene-Oligocene Andaman Flysch Group, Andaman Islands, India; Gondwana Res. 4 477-487.

Chakraborty P P, Pal T, Duttagupta T and Gupta K S 1999 Facies pattern and depositional motif in an immature trench-slope basin, Eocene Mithakhari Group, Middle Andaman, India; J. Geol. Soc. India 53 271-284.

Chakraborty P P and Khan P K 2009 Cenozoic geodynamic evolution of the Andaman-Sumatra subduction margin: Current understanding; Island Arc. 18 184-200.

Chatterjee A K 1964 The Tertiary fauna of Andaman (ed.) Sunduram R K, Int. Geol. Cong. Rept., 22nd Session, New Delhi, pp. 303-318.

Chatterjee P K 1967 Geology of the main islands of the Andaman; In: Proc. Symp. Upper Mantle Project, NGRI, Hyderabad, India, pp. 348-362.

Condie K C, Noll (Jr) P D and Conway C M 1992 Geochemical and detrital mode evidence for two sources of early Proterozoic sedimentary rocks from the Tonto basin Supergroup, central Arizona; Sedim. Geol. 77 51-76.

Critelli S 1993 Sandstone detrital modes in the Paleogene Liguride complex, accretionary wedge of the southern Apennines (Italy); J. Sedim. Petrol. 63 464-476.

Critelli S, De Rosa R and Platt J P 1990 Sandstone detrital mode in the Makran accretionary wedge, southwest Pakistan: Implications for tectonic setting and long distance turbidite transportation; Sedim. Geol. 68 241-260.

Crook K A W 1974 Lithogenesis and geotectonics: The significance of compositional variation in flysch arenites (greywackes); Soc. Econ. Paleontol. Mineral. Spec. Publ. $19304-310$.

Curray J R 2005 Tectonics and history of the Andaman Sea region; J. Asian Earth Sci. 25 187-232.

Curray J R and Allen R 2008 Evolution, paleogeography and sediment provenance, Bay of Bengal, Indian Ocean; Golden Jubilee Memoir, Geol. Soc. India 66 487-520.

Dickinson R W 1970 Interpreting detrital modes of greywacke and arkose; J. Sedim. Petrol. 40 695-707.

Dickinson W R and Suczek C A 1979 Plate tectonics and sandstone compositions; Am. Assoc. Petrol. Geol. 63 2164-2182.

Dickinson W R, Beard L S, Brakenridge G R, Erjavec J L, Ferguson R C, Inman K, Knepp R A, Lindberg F A and Ryberg P T 1983 Provenance of North American Phanerozoic sandstones in relation to tectonic setting; Geol. Soc. Am. Bull. 94 222-235.

Fedo C M, Nesbitt H W and Young G M 1995 Unravelling the effects of potassium metasometism in sedimentary rocks and paleosols, with implications for paleoweathering conditions and provenance; Geology 23 921-923.

Garver J I, Royce P R and Smick T A 1996 Chromium and nickel in shale of the Taconic foreland: A case study for the provenance of fine-grained sediments with an ultramafic source; J. Sedim. Res. 66 100-106.

Garzanti E and Van Haver T 1988 The Indus clastics: Forearc basin sedimentation in the Ladakh Himalaya (India); Sedim. Geol. 59 237-249. 
Garzanti E and Vezzoli G 2003 A classification of metamorphic grains in sands based on their composition and grade; J. Sedim. Res. 73 830-837.

Garzanti E, Doglioni C, Vezzoli G and Ando S 2007 Orogenic belts and orogenic sediment provenance; J. Geol. $115315-334$.

Garzanti E, Limonta M, Resentini A, Bandopadhyay P C, Najman Y, Ando S and Vezzoli V 2013a Sediment recycling at convergent plate margins: Indo-Burman Ranges and Andaman-Nicobar Ridge; Earth Sci. Rev. 123 113-132.

Garzanti E, Padoan M, Ando S, Resentini A, Vezzoli G and Lustrino M 2013b Weathering and relative durability of detrital minerals in equatorial climate: Sand petrology in the East African rift; J. Geol. 121 547-580.

Ghosh B, Pal T, Bhattacharya A and Das D 2009 Petrogenetic implications of ophiolitic chromite from Rutland Island, Andaman - a boninitic parentage in supra-subduction setting; Mineral. Petrol. 96 59-70.

Ghosh S, Sarkar S and Ghosh P 2012a Petrography and major element geochemistry of the Permo-Triassic sandstones, central India: Implications for provenance in an intracratonic pull-apart basin; J. Asian Earth Sci. 43 207-240.

Ghosh B, Morishita T and Bhatta K 2012b Detrital chromian spinels from beach placers of Andaman Islands, India: A perspective view of petrological characteristics and variations of the Andaman ophiolite; Island Arc. 21 188-201.

Gromet L P, Dymek R F, Haskin L A and Korotev R L 1984 The North American shale composite: Its implications, major and trace elements characteristics; Geochim. Cosmochim. Acta 48 2469-2482.

Haldar D 1985 Some aspects of Andaman ophiolite complex; Rec. Geol. Surv. India 115 1-11.

Hiscott R N 1984 Ophiolitic source rocks for Taconic-age flysch: Trace element evidence; Geol. Soc. Am. Bull. 95 1261-1267.

Ingersoll R V 1983 Petrofacies and provenance of late Mesozoic forearc basin, northern and central California; Bull. Am. Assoc. Petrol. Geol. 67 1125-1142.

Ingersoll R V and Suczek C A 1979 Petrology and provenance of Neogene sand from Nicobar and Bengal fans, DSDP sties 211 and 218; J. Sedim. Petrol. 49 1217-1228.

Islam R, Ghosh S K and Sachan H K 2002 Geochemical characterization of the Neoproterozoic Nagthat siliciclastics, NW Kumaun Lesser Himalaya: Implications for source rock assessment; J. Geol. Soc. India 60 91105.

Jacobson A D, Blum J D, Chamberlian C P, Craw D and Koons P O 2003 Climate and tectonic controls on chemical weathering in the New Zealand Southern Alps; Geochim. Cosmochim. Acta 37 29-46.

Jafri S H and Sheikh J M 2013 Geochemistry of pillow basalts from Bompoka, Andaman-Nicobar Islands, Bay of Bengal, India; J. Asian Earth Sci. 64 27-37.

Jafri S H, Balaram V and Govil P K 1993 Depositional environments of Cretaceous radiolarian cherts from Andaman-Nicobar Islands, northeastern Indian Ocean; Mar. Geol. 112 291-301.

Karunakaran C, Pawde M B, Raina V K and Ray K K 1964a Geology of the South Andaman Island, India; Reports of the $22^{\text {nd }}$ Int. Geol. Cong., New Delhi, India, XI. 79-100.

Karunakaran C, Ray K K and Saha S S 1964b Sedimentary environment of the formation of Andaman Flysch, Andaman Islands, India; Reports of the 22nd Int. Geol. Cong., New Delhi, India, XV. 226-232.

Karunakaran C, Ray K K and Saha S S 1968 Tertiary sedimentation in Andaman-Nicobar geosynclines; J. Geol. Soc. India 9 32-39.
Khan P K and Chakraborty P P 2005 Two-phase opening of Andaman Sea: A new seismotectonic insight; Earth Planet. Sci. Lett. 229 259-71.

Le Bas M J, Le Maitre R W, Streckeisen A and Zanettinal B 1986 A chemical classification of volcanic rocks based on the total alkali-silica diagram; J. Petrol. 27 745-750.

Le Maitre R W 1976 The chemical variability of some common igneous rocks; J. Petrol. 17 589-637.

Long X, Sun M, Yuan C, Xiao W and CAI K 2008 Early Paleozoic sedimentary record of the Chinese Altai: Implications for its tectonic evolution; Sedim. Geol. 208 $88-100$.

Mattern F 2005 Ancient sand-rich submarine fans: Depositional systems, models, identification, and analysis; Earth Sci. Rev. 70 167-202.

Maynard J B, Valloni R and Yu H S 1982 Composition of modern deep-sea sands from arc-related basins. Trenchforearc geology: Sedimentation and tectonics on modern and ancient active plate margins (ed.) Legget J K, Geol. Soc. Am. Spec. Paper 284 21-40.

McLennan S M, Taylor S R and Eriksson K A 1983 Geochemistry of Archean shales from the Pilbara Supergroup, western Australia; Geochim. Cosmochim. Acta 47 1211-1222.

McLennan S M, Taylor S R, McCulloch M T and Maynard J B 1990 Geochemical and Nd-Sr isotope composition of deep-sea turbidites: Crustal evolution and plate tectonic associations; Geochim. Cosmochim. Acta $\mathbf{5 4}$ 2015-2050.

McLennan S M, Hemming S, McDaniel D K and Hanson G N 1993 Geochemical approaches to sedimentation, provenance, and tectonics; In: Processes controlling the composition of clastic sediments (eds) Johnson M J and Basu A, Geol. Soc. Am. Spec. Paper 284 21-40.

Mitchell A H G 1993 Cretaceous-Cenozoic tectonic events in the western Myanmar (Burma)-Assam region; J. Geol. Soc. London 150 1089-1102.

Moore G F 1979 Petrography of subduction zone sandstones from Nias Island, Indonesia; J. Sedim. Petrol. 49 71-84.

Nesbitt H W and Young G M 1982 Early Proterozoic climates and plate motions inferred from major element chemistry of lutites; Nature 299 715-717.

Nesbitt H W and Young G M 1984 Prediction of some weathering trends of plutonic and volcanic rocks based on thermodynamics and kinetic considerations; Geochim. Cosmochim. Acta 48 1523-1534.

Pal T 2011 Petrology and geochemistry of the Andaman ophiolite: Melt-rock interaction in a suprasubductionzone setting; J. Geol. Soc. London 168 1031-1045.

Pal T and Bhattacharya A 2010 Greenschist-facies, subophiolitic metamorphic rocks of Andaman Islands, Burma-Java subduction complex; J. Asian Earth Sci. 39 804-814.

Pal T, Chakraborty P P, Duttagupta T and Singh D 2003 Geodynamic evolution of outer arc-forearc belt in the Andaman Islands, the central part of the Burma-Java subduction complex; Geol. Mag. 140 289-307.

Pandey J, Agarwal R P, Dave A, Maithani A, Trivedi K B, Srivastava A K and Singh D N 1992 Geology of Andaman; Bull. ONGC 2(2) 19-103.

Pedersen R B, Searle M P, Carter A and Bandopadhyay P C 2010 U-Pb zircon age of Andaman ophiolite: Implications for the beginning of subduction beneath the AndamanSumatra subduction arc; J. Geol. Soc. London 167 11051112.

Rahman M J and Suzuki S 2007 Geochemistry of sandstones from the Miocene Surma Group, Bengal Basin, Bangladesh: Implications for provenance, tectonic setting and weathering; Geochem. J. 41 415-428. 
Rajashekhar C and Reddy P P 2003 Quaternary stratigraphy of the Andaman-Nicobar Islands, Bay of Bengal; J. Geol. Soc. India 62 485-493.

Raju K A K 2005 Three-phase tectonic evolution of the Andaman backarc basin; Curr. Sci. 89(11) 1932-1936.

Rashid S A 2002 Geochemical characteristics of Mesoproterozoic clastic sedimentary rocks from Chakrata Formation, Lesser Himalaya: Implications for crustal evolution and weathering history in the Himalaya; $J$. Asian Earth Sci. 21 283-293.

Raza M, Casshyap S M and Khan A 2002 Geochemistry of Mesoproterozoic Lower Vindhyan shales from Chattaurgarh, southeastern Rajasthan and its bearing on source rock composition, paleoweathering conditions and tectono-sedimentary environments; J. Geol. Soc. India 60 $505-518$.

Roser B P and Korsch R J 1986 Determination of tectonic setting of sandstone--mudstone suites using $\mathrm{SiO}_{2}$ content and $\mathrm{K}_{2} \mathrm{O} / \mathrm{Na}_{2} \mathrm{O}$ ratio; J. Geol. 94 635-650.

Roy D K, Acharyya S K, Ray K K, Lahri T C and Sen M K 1988 Nature of occurrence, age and depositional environment of the oceanic pelagic sediments associated with ophiolite assemblage, South Andaman Island, India; Indian Minerals 42 31-65.

Roy T K 1983 Geology and hydrocarbon prospects of Andaman-Nicobar; In: Petroliferous Basins of India (eds) L L Bhandari et al., Petroleum Asia J., pp. 3-50.

Sarma D S, Jafri S H, Fletcher I R and McNaughton N J 2010 Constraints on the tectonic setting of the Andaman ophiolites, Bay of Bengal, India, from SHRIMP $\mathrm{U}-\mathrm{Pb}$ zircon geochronology of plagiogranite; J. Geol. 118 691-697.
Sharma V and Srinivasan M S 2007 Geology of AndamanNicobar: The Neogene; Capital Publishing Company, New Delhi, Kolkata, Bangalore.

Taylor S R and McLennan S M 1985 The Continental Crust: Its composition and evolution; Blackwell Publishing Company, USA, UK, Australia, 311p.

Tucker M E 2001 Sedimentary petrology: An introduction to the origin of sedimentary rocks; 3rd edn, Blackwell Publishing Company, USA, UK, Australia, India, pp. 1-251.

Turekian K K and Wedepohl K H 1961 Distribution of the elements in some major units of the earth's crust; Geol. Soc. Am. Bull. 72 175-192.

Verma S P and Armstrong-Altrin J S 2013 New multidimensional diagrams for tectonic discrimination of siliciclastic sediments and their application to Precambrian basins.

Vohra C P, Haldar D and Gosh Roy A K 1989 The Andaman-Nicobar ophiolite complex and associated mineral resources-current appraisal; In: Phanerozoic ophiolite of India (ed.) Ghosh N C, Sumana Publisher, Patna, India, pp. 281-315.

Wrafter J P and Graham J R 1989 Short Paper: Ophiolitic detritus in the Ordovician sediments of South Mayo, Ireland; J. Geol. Soc. London 146 213-215.

Wronkiewicz D J and Condie K C 1987 Geochemistry of Archean shales from the Witwatersrand Supergroup, South Africa: Source-area weathering and provenance; Geochim. Cosmochim. Acta 51 2401-2416.

Young G M and Nesbitt H W 1998 Process controlling the distribution of $\mathrm{Ti}$ and $\mathrm{Al}$ in weathering profiles, siliciclastic sediments and sedimentary rocks; J. Sedim. Res. 68 448455. 